\title{
New Zealand: 2008 Article IV Consultation-Staff Report; and Public Information Notice on the Executive Board Discussion
}

Under Article IV of the IMF's Articles of Agreement, the IMF holds bilateral discussions with members, usually every year. In the context of the 2008 Article IV consultation with New Zealand, the following documents have been released and are included in this package:

- The staff report for the 2008 Article IV consultation, prepared by a staff team of the IMF, following discussions that ended on March 3, 2008, with the officials of New Zealand on economic developments and policies. Based on information available at the time of these discussions, the staff report was completed on April 17, 2008. The views expressed in the staff report are those of the staff team and do not necessarily reflect the views of the Executive Board of the IMF.

- A Public Information Notice (PIN) summarizing the views of the Executive Board as expressed during its May 9, 2008 discussion of the staff report that concluded the Article IV consultation.

The document listed below has been or will be separately released.

\section{Selected Issues Paper}

The policy of publication of staff reports and other documents allows for the deletion of market-sensitive information.

\author{
Copies of this report are available to the public from \\ International Monetary Fund • Publication Services \\ $70019^{\text {th }}$ Street, N.W. • Washington, D.C. 20431 \\ Telephone: (202) 623-7430 • Telefax: (202) 623-7201 \\ E-mail: publications@imf.org・Internet: http://www.imf.org
}

Price: $\$ 18.00$ a copy

\section{International Monetary Fund \\ Washington, D.C.}



INTERNATIONAL MONETARY FUND

NEW ZEALAND

Staff Report for the 2008 Article IV Consultation

Prepared by the Asia and Pacific Department

(In consultation with other departments)

Approved by Steven Dunaway and Scott Brown

April 17, 2008

- Discussions: Auckland and Wellington, February 22-March 3, 2008, with the Minister of Finance Michael Cullen, the Governor of the Reserve Bank of New Zealand Alan Bollard, the Treasury Secretary John Whitehead, and other senior officials and representatives of the private sector and trade unions.

- Team: Mr. Brooks (head), Mr. Hunt, Ms. Edison, and Mr. Rozhkov (all APD).

Mr. Dunaway (APD) and Mr. Ha (OED) also participated in the meetings.

- Mission Focus: Macroeconomic policies needed to cool the economy and reduce external vulnerabilities.

- Past Fund Advice: For a description of policy issues discussed in the 2007 Article IV consultation, see http://www.imf.org/external/np/sec/pn/2007/pn0751.htm.

- Exchange System: New Zealand has accepted the obligations of Article VIII, Sections 2, 3, and 4 . The exchange rate is free of restrictions on the making of payments and transfers for current international transactions other than restrictions notified to the Fund in accordance with Decision No. 144-(52/51).

- Official Development Assistance: New Zealand has budgeted 0.3 percent of national income for ODA in 2007/08, focused on the Pacific. 
Executive Summary 3

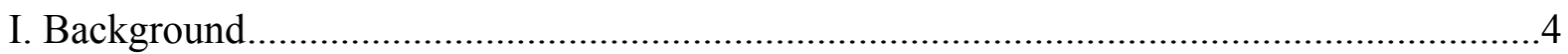

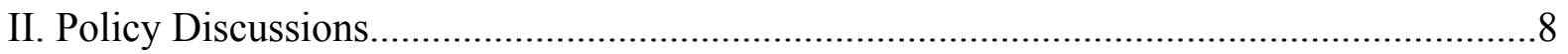

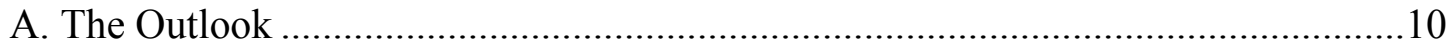

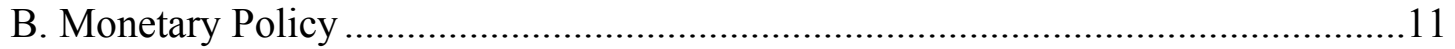

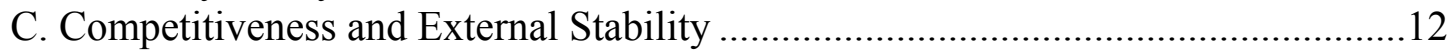

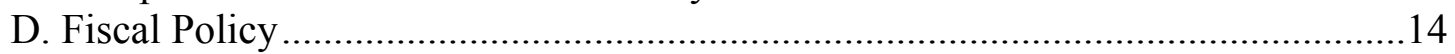

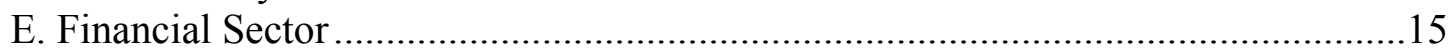

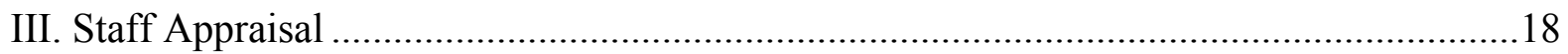

Boxes

1. What Was the Impact of the Global Financial Turmoil on New Zealand? .................9

2. New Zealand's Equilibrium Real Exchange Rate ...................................................13

3. How Overvalued are New Zealand House Prices? .................................................. 17

Figures

1. Prolonged Expansion Leads to Overheating ............................................................4

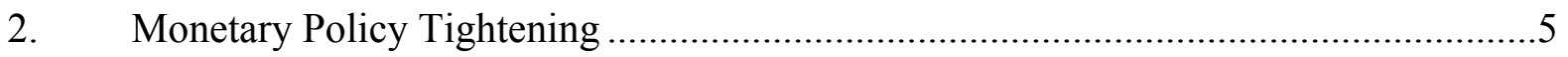

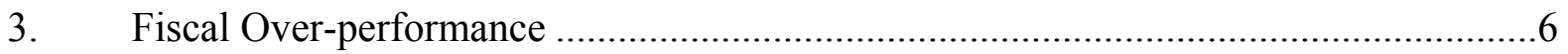

4. The Exchange Rate and External Liabilities...........................................................

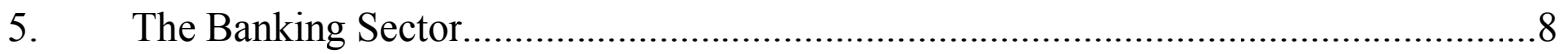

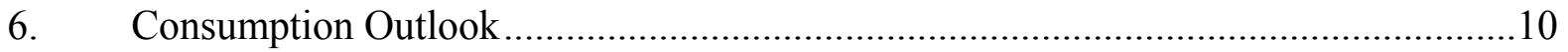

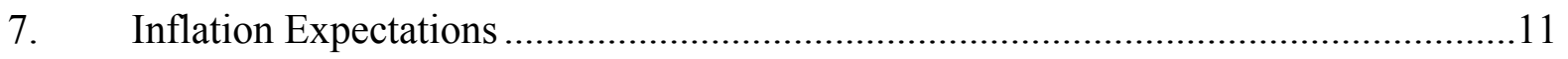

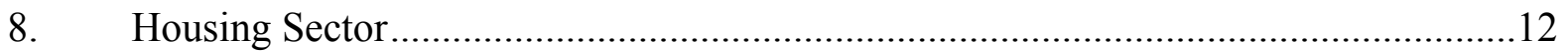

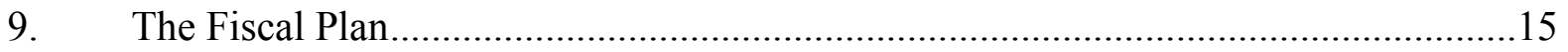

10. External Debt Sustainability: Bound Tests ........................................................24

Tables

1. Selected Economic and Financial Indicators, 2004-09 .......................................20

2. Summary of Central Government Budget, 2003/04-2007/08 .................................21

3. Balance of Payments and External Debt, 2003-08...............................................22

4. Medium-Term Scenario, 2007-13 ...................................................................23

Appendixes

I. Exchange Rate Assessment Methodology ..............................................................25 


\section{Executive Summary}

Sound economic policies have resulted in 10 years of robust economic expansion, but capacity constraints have emerged in recent years. Inflation pressures have increased, driven in part by a housing boom, and monetary policy has been tightened since 2004 . Capital inflows, attracted by wide interest rate differentials, worsened the current account deficit and increased external vulnerability. The authorities and staff agreed that growth is likely to slow in 2008, but that the outlook is more uncertain than usual. On the upside, strong household income growth could sustain domestic demand, while on the downside the uncertain external environment poses significant risks.

The current stance of monetary policy is appropriate. During 2007, retail mortgage rates became more responsive to the official cash rate, and this is having the desired effect of moderating house price inflation and slowing overall activity. More recently, tightening international credit conditions have also contributed to mortgage rate increases that should help ease capacity pressures. With significant risks present, the authorities and staff agreed that monetary policy should remain on hold pending clearer indications of the future path of the economy.

Although inflows of foreign capital have contributed to the appreciation of the currency, the strength in commodity prices has also been an important factor. Staff estimates suggest that the real effective exchange rate (REER) is overvalued by 5-15 percent. The authorities and staff agreed that capital inflows are likely to ease and the overvaluation to unwind, as inflation pressures moderate and the policy rate normalizes. However, the equilibrium level of the currency is likely to remain above its historical average because a portion of the rise in commodities prices will likely be permanent.

A reduction in budget surpluses over time is consistent with prudent fiscal policy, but caution is needed in the near term to dampen inflation pressures. The staff advised that flexibility be maintained in the magnitude and the timing of the easing so that the fiscal stimulus will not occur until inflation pressures are expected to have abated and it is clear that fiscal resources exist to deliver tax and spending measures. The authorities recognized the need for fiscal policy to support monetary policy, but considered that the supply-side benefits of lower income taxes and improved infrastructure were also important.

The financial sector remains sound but vulnerabilities exist. Banks are profitable, well capitalized, and asset quality appears to be high. However, banks' assets are concentrated in residential mortgages, and banks have significant short-term international wholesale funding. The current tightening in international capital markets is putting upward pressure on bank funding costs and highlighting rollover risks.

The vulnerabilities in the banking sector present some policy challenges. A further disruption to capital inflows that raises demand for domestic liquidity would need to be accommodated by the Reserve Bank of New Zealand (RBNZ). In addition, the staff welcomed steps being taken by the RBNZ to develop and implement guidelines aimed at improving banks' liquidity management. 


\section{BACKGROUND}

1. New Zealand has experienced a decade-long economic expansion, but capacity constraints have emerged in recent years. Sound macroeconomic policies combined with structural reforms in the 1990s resulted in growth averaging almost $3 \frac{1}{2}$ percent annually between 1998 and 2007. However, as the expansion continued, capacity utilization rose and unemployment fell to historical lows (Figure 1). This combined with rapidly appreciating house and share prices resulted in demand pressures. As resource pressures mounted, nontradables inflation increased and domestic demand became increasingly satisfied with imports, widening the current account deficit to more than 8 percent of GDP (Table 1).

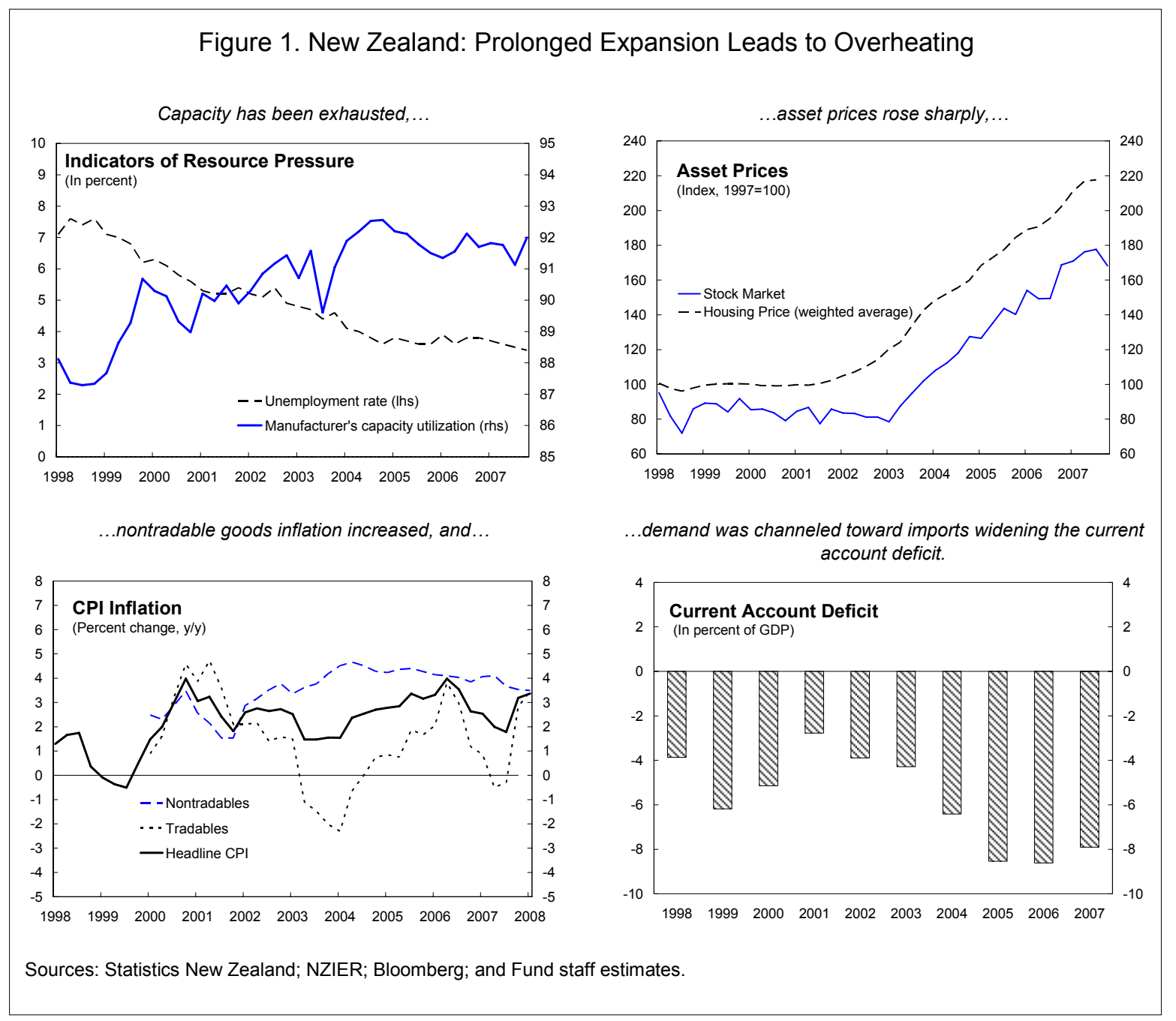


2. The authorities tightened monetary policy in response to rising inflation, but abundant international liquidity muted the impact. The RBNZ raised the official cash rate (OCR) from 5.0 percent in 2003 to its current level of 8.25 percent, with four 25 basis point increases in the first half of 2007 (Figure 2). However, competition in the mortgage market, in part reflecting banks' access to abundant international liquidity until the recent turmoil in global markets, reduced the transmission into mortgage rates. As a result, the housing boom, initially coinciding with an immigration spurt, remained surprisingly resilient, supporting household wealth and domestic demand. Searching for yield, international investors responded to the wide interest rate differential, and inflows of foreign capital appreciated the exchange rate.

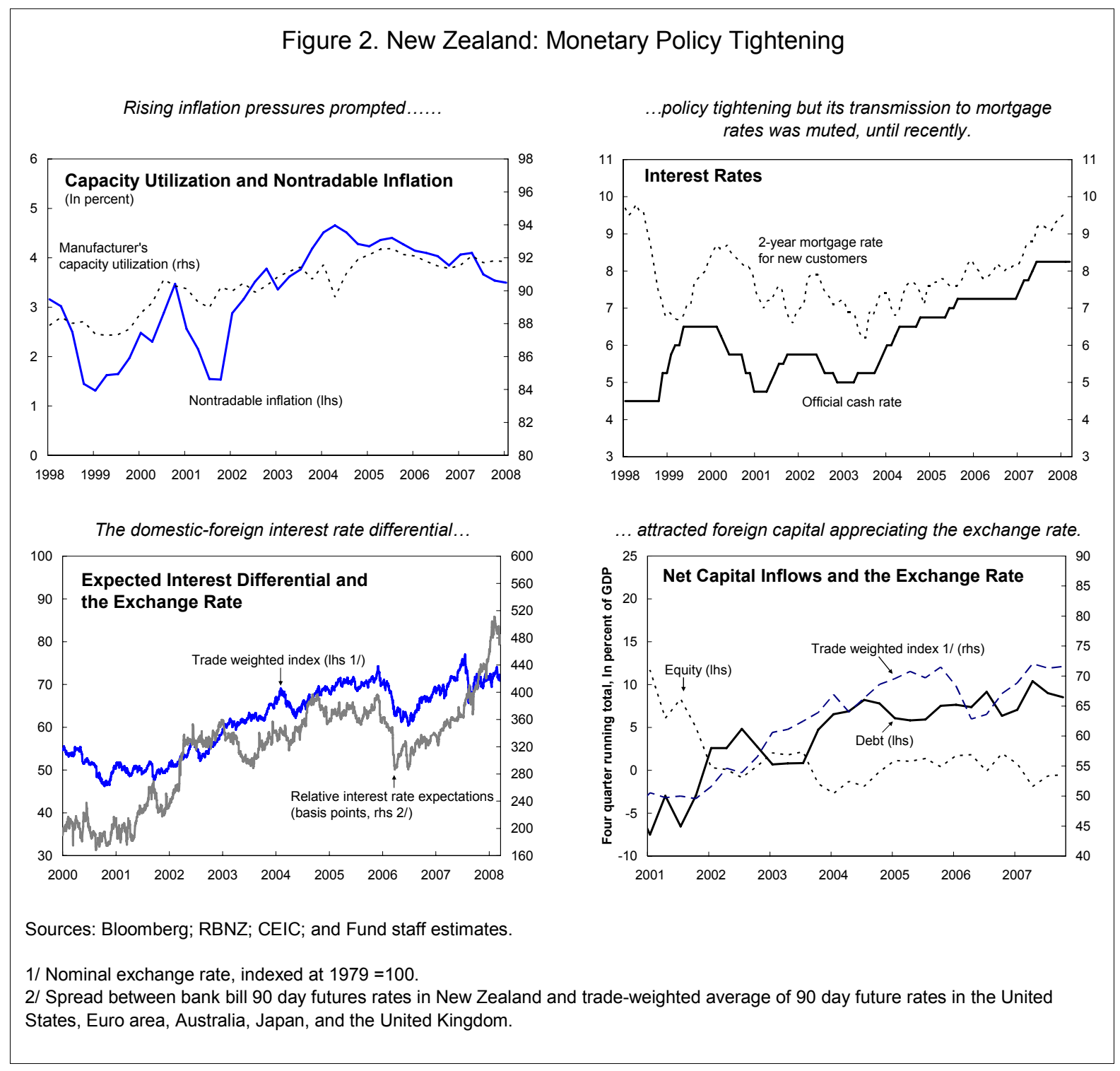


3. Fiscal surpluses emerged well in excess of the 2 percent of GDP implied by the medium-term framework. ${ }^{1}$ Revenue consistently surprised on the upside in recent years, driven by the stronger-than-expected economy and surprising buoyancy in corporate tax revenue (Figure 3, Table 2). Most of the revenue over-performance was saved, moving the public sector into a positive net financial asset position. However, the strong fiscal performance has increased pressures to bring the fiscal position more in line with the medium-term targets by cutting taxes and increasing spending. Expenditure measures over the last three years have offset some of the restraint from automatic stabilizers, with the fiscal stance expected to be stimulative in 2007/08.

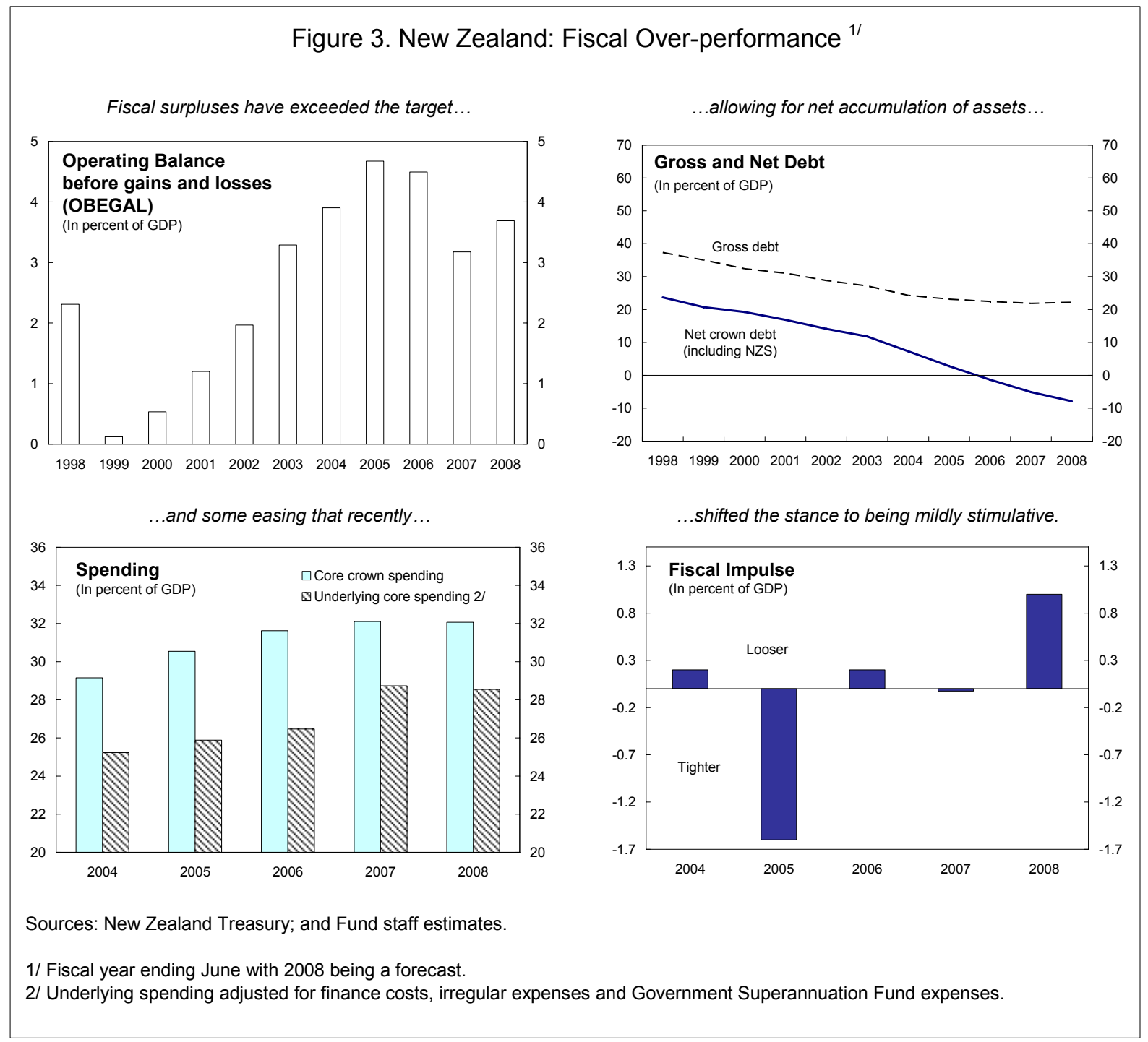

\footnotetext{
${ }^{1}$ A surplus of about 2 percent of GDP is consistent with the authorities' objective of maintaining a prudent level of debt (gross debt of less than 20 percent of GDP) and accumulating assets in the publicly managed superannuation fund to help address long-term pension costs.
} 


\section{Large current account deficits have contributed to an increase in external}

liabilities. The trade balance worsened as the exchange rate appreciated while the income deficit widened to 71/4 percent of GDP in 2007 as domestic interest rates rose (Figure 4, Table 3). Consequently, net foreign liabilities increased to almost 90 percent of GDP, accumulating primarily as debt on banks' balance sheets.

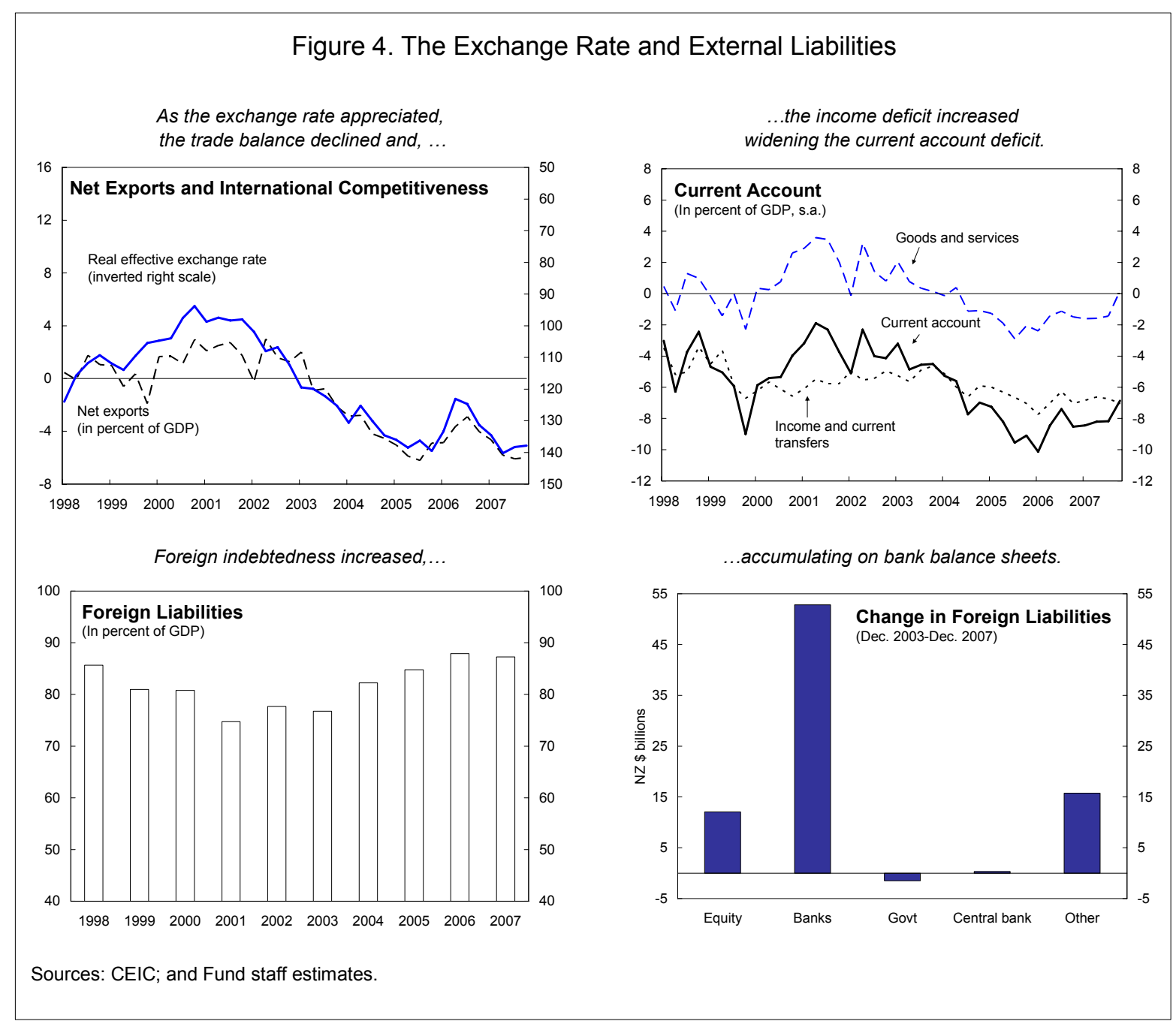

5. The banking sector is sound, but the rise in external debt has increased banks' exposure to international capital markets. Traditional indicators - stable profits, high capitalization, and few nonperforming loans - suggest a healthy banking sector (Figure 5). However, the recent global financial market turbulence raised funding costs (Box 1) and highlighted the rollover risk associated with banks' short-term funding from international wholesale debt markets. On the asset side, the large mortgage book (45 percent of assets) leaves banks exposed to households, whose debts exceed 160 percent of disposable income, while debt-servicing costs have risen to $14 \frac{1}{2}$ percent of disposable income. At present, nonperforming loans in the banking system amount to only 0.1 percent of total loans. 
Figure 5. New Zealand: The Banking Sector

Traditional indicators suggest banks are healthy, but...

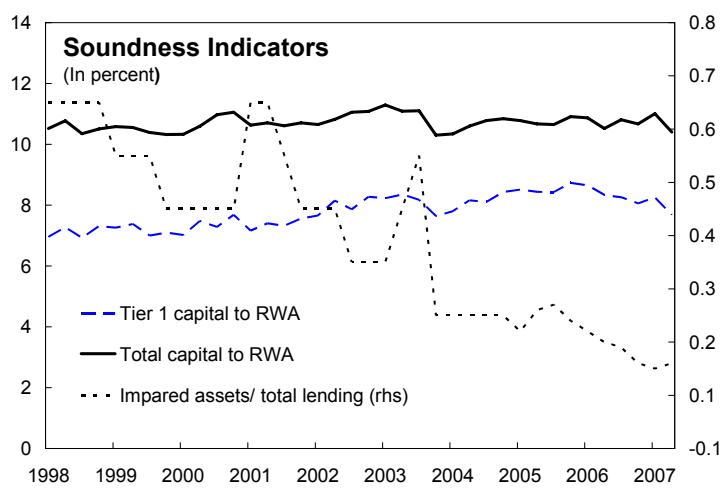

...and are highly exposed to households...

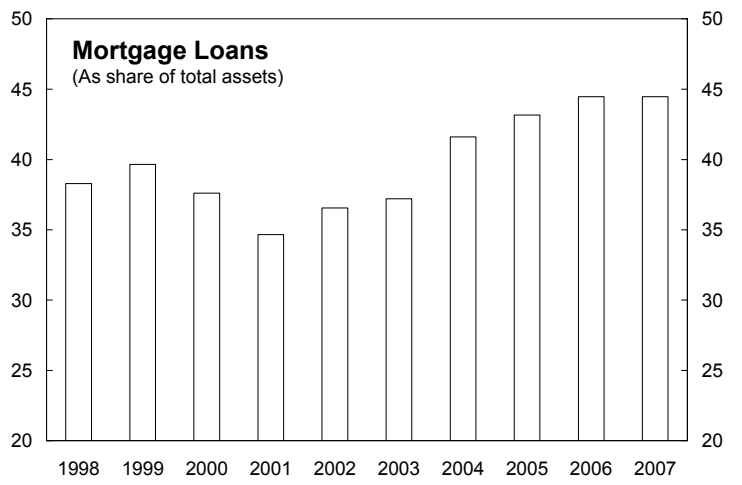

Sources: RBNZ and Fund staff estimates. ...they are dependent on wholesale funding...

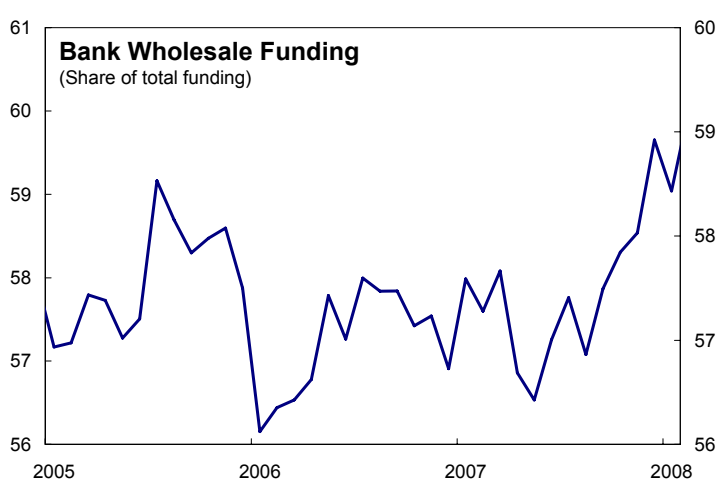

.which have become heavily indebted.

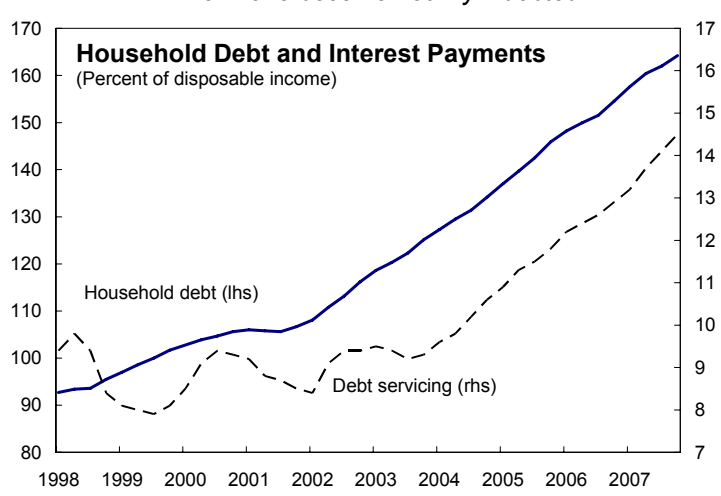

\section{Policy Discussions}

6. Discussion focused on the macroeconomic policies needed to cool the economy and reduce external vulnerabilities, including:

- the appropriate degree of monetary restraint to reduce inflationary pressures while balancing the risks associated with an uncertain external environment;

- $\quad$ the fiscal restraint required to avoid placing undue pressure on monetary policy; and

- $\quad$ the policy reaction to the fallout from global financial market turmoil. 


\section{Box 1. What Was the Impact of the Global Financial Turmoil on New Zealand?}

The direct effect of the U.S. sub-prime crisis was minimal as New Zealand banks report virtually no exposure to U.S. sub-prime investments or affected markets in other countries. In addition, securitization is not common in New Zealand, with less than 1 percent of banks' mortgage loans funded through mortgage-backed securities.

The main impact of the turmoil was an increase in funding costs in offshore wholesale debt markets, which account for more than $1 / 3$ of total funding for New Zealand banks. As a result, banks have competed more vigorously for funding in the domestic market since July last year, causing bank bill yields to increase relative to the overnight indexed swap (the market expectation of the OCR) by $25-50$ basis points above the normal spread (see figure below). Also, in recent months the credit default swap (CDS) rates for the major Australian banks that own the four large New Zealand banks have widened sharply (see figure below), also indicating a higher cost of funding.

During the turmoil, banks had sufficient liquidity to meet payment obligations. The RBNZ provided interbank liquidity by increasing settlement cash and allowing banks to use a wider range of instruments in the overnight reverse repurchase facility. These measures were similar to actions taken by other central banks in late 2007 .

While the banking system remains sound, several finance companies experienced difficulties in mid-2007 and were put into receivership. Liquidity pressures arising from the turmoil were the trigger for closure in some cases, but these failures were caused primarily by problems with asset quality, connected lending, and credit management. However, finance companies are a small segment of the financial system (3 percent of total assets), and the failures are not expected to undermine the stability of the system given that the failed companies comprise only 0.3 percent of total system assets.
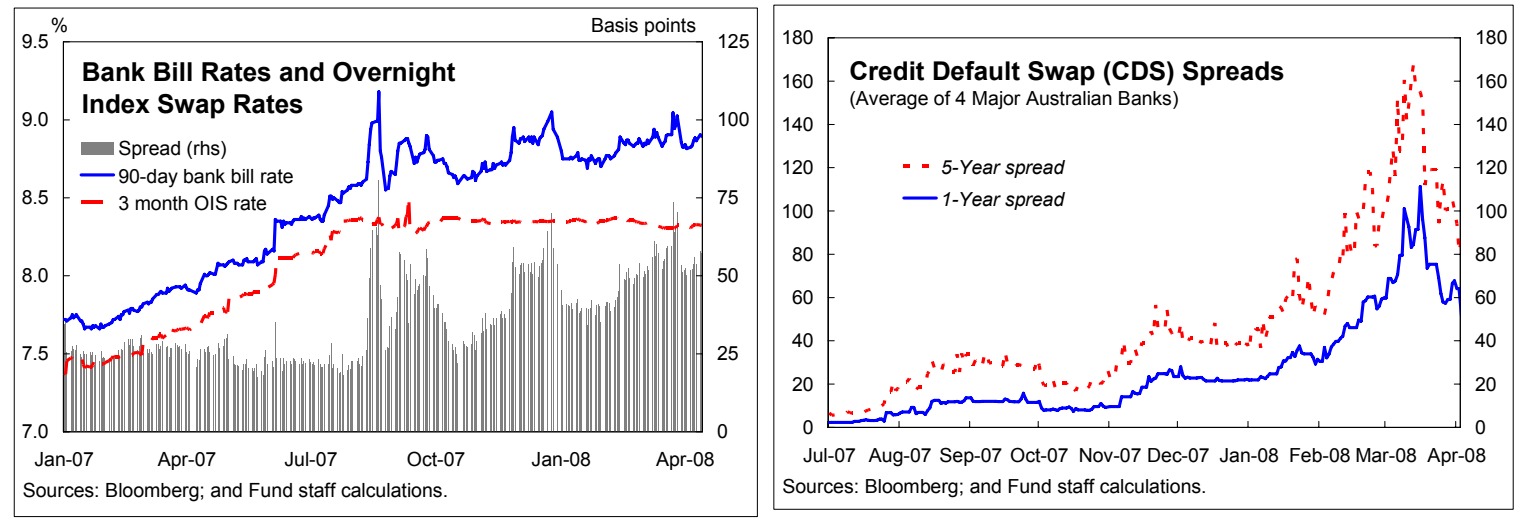


\section{A. The Outlook}

7. There was broad agreement that activity is slowing. Staff projects growth to moderate to about 2 percent in 2008 and 2009. A cooling housing market, rising debtservicing costs and weaker consumer sentiment should restrain private consumption and residential investment, despite continued strength in incomes (Figure 6). The rising cost of capital, owing to re-pricing of risk, should curb business investment. External demand is also expected to moderate as the U.S. downturn and tighter credit conditions flow through to activity in the rest of the world. In addition, an extended dry period in early 2008 will adversely affect farm incomes. CPI inflation is projected to remain above 3 percent over 2008, before easing in 2009.

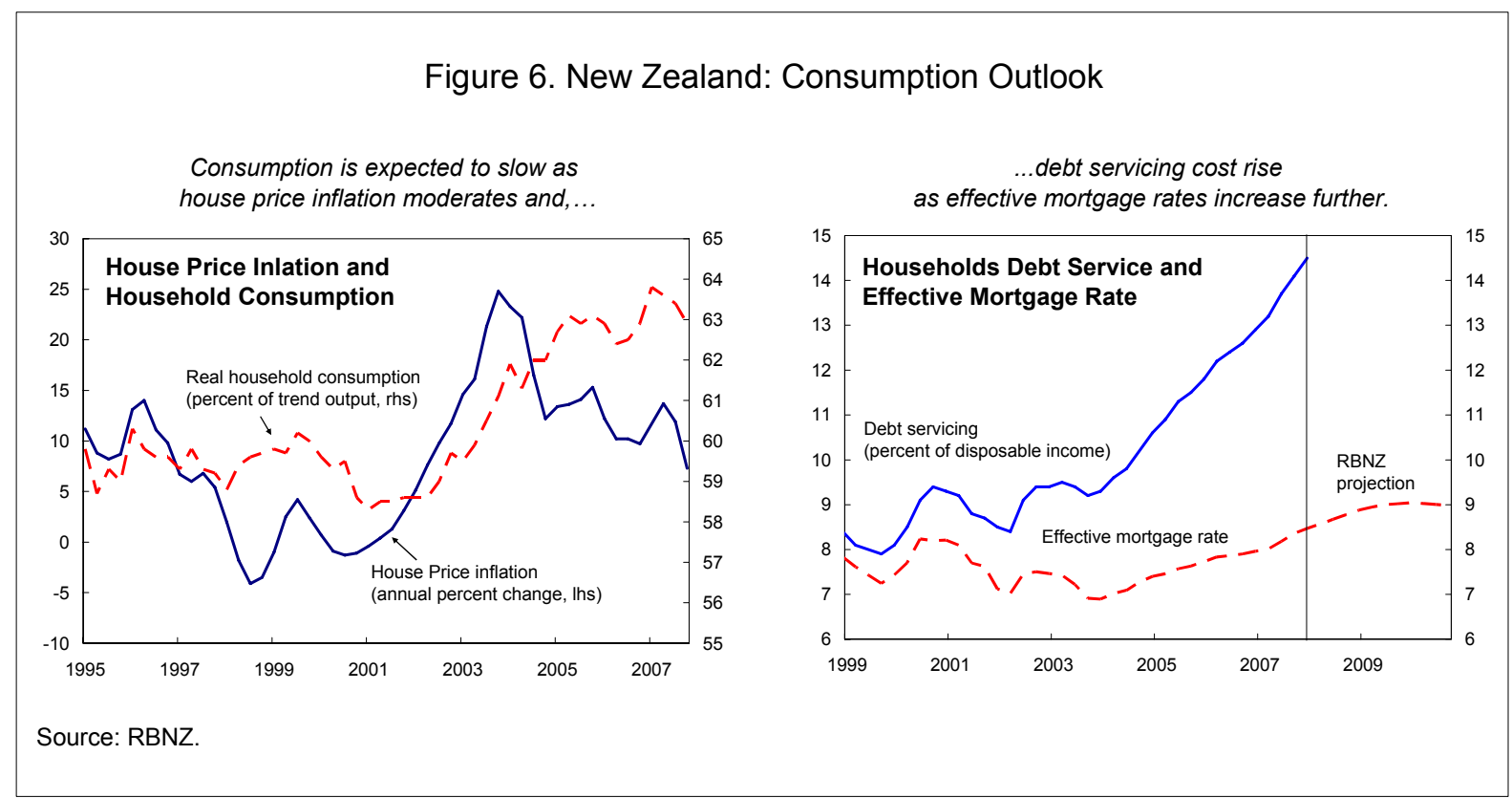

8. High commodity prices and slowing domestic demand will narrow the current account deficit, even under the assumption of a constant REER at end-2007 levels, which underlies staff forecasts. But, as inflationary pressures abate and the official cash rate returns to a more neutral level in 2009/10, a reduction in capital inflows should lead to an exchange rate depreciation and help the current account adjust further. In turn, this would slow the accumulation of external liabilities and help to contain vulnerability.

\section{Uncertainty regarding the economy's prospects, however, is greater than usual.}

The impact on incomes from high commodity prices and wage growth could maintain domestic capacity pressures. In contrast, the impact of the U.S. downturn on trading-partner growth could be larger than expected, sharply dampening external demand. Also, because of banks' dependence on wholesale markets for funding, continued tightening in international credit conditions could increase further the servicing costs for heavily indebted New Zealand households, squeezing domestic demand 


\section{B. Monetary Policy}

\section{The persistence of inflation pressures argues for maintaining a firm monetary}

policy stance. The tight labor market, strong income growth (especially for dairy farmers), and the prospect of fiscal stimulus are keeping inflation high even with a cooling in the housing market. ${ }^{2}$ In addition, the authorities noted that rising energy and food prices, together with the introduction of an emissions trading scheme, is increasing inflation expectations and making it more difficult to reduce inflation. The authorities agreed on the need to respond if the slowing in trading partner growth or the fallout from financial market turmoil is worse than expected. However, given the uncertainties at present, the

Figure 7. New Zealand: Inflation Expectations

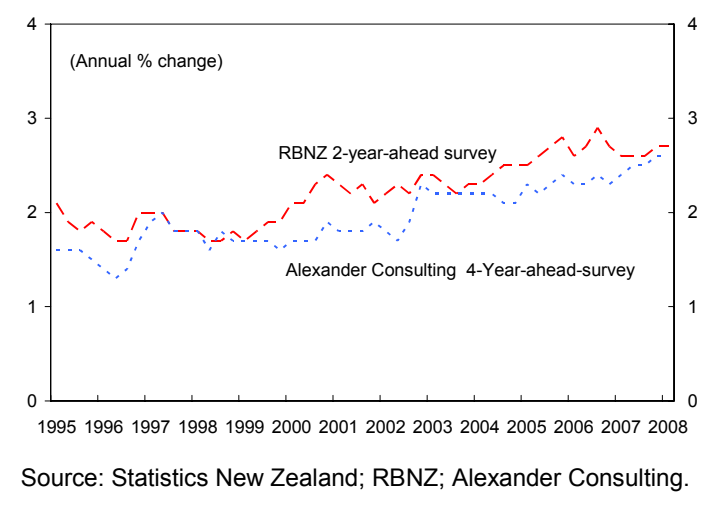
authorities and the staff agreed that monetary policy should remain on hold pending clearer indications of the future path of the economy.

11. A sharp slowdown in the housing market is underway (Figure 8). This is key to containing inflation as it will slow construction activity and dampen consumption through wealth effects and reduced availability of home equity financing. Earlier concerns about the lack of effectiveness of monetary policy in containing the housing boom in the face of the carry trade have lessened. The effective mortgage rate has risen by 160 basis points since the tightening cycle began in 2004, with the increased cost of funding arising from the global turmoil a contributing factor. At least another 50-basis points increase in the effective mortgage rate is in prospect through late 2009 due to interest rate resets for fixed mortgages (if new mortgage rates stay around current levels). ${ }^{3}$

\section{A parliamentary inquiry into the monetary policy framework is nearing} completion. The inflation-targeting framework has evolved over time, and has been based since 2002 on a more flexible target of " $1-3$ percent on average over the medium term." Despite the increased flexibility, concerns about an overvalued exchange rate sparked the inquiry, which provided a useful forum for discussing the benefits and costs associated with the inflation-targeting framework. The framework has delivered a prolonged period of relatively low inflation accompanied by economic growth, therefore the staff advised against any significant changes in the framework.

\footnotetext{
${ }^{2}$ Higher world dairy prices should boost dairy farmer incomes by $1 \frac{1}{2}-2$ percent of GDP in 2007/08.

${ }^{3}$ Half of fixed mortgages will reset within the next 20 months, with fixed mortgages comprising four-fifths of mortgages.
} 


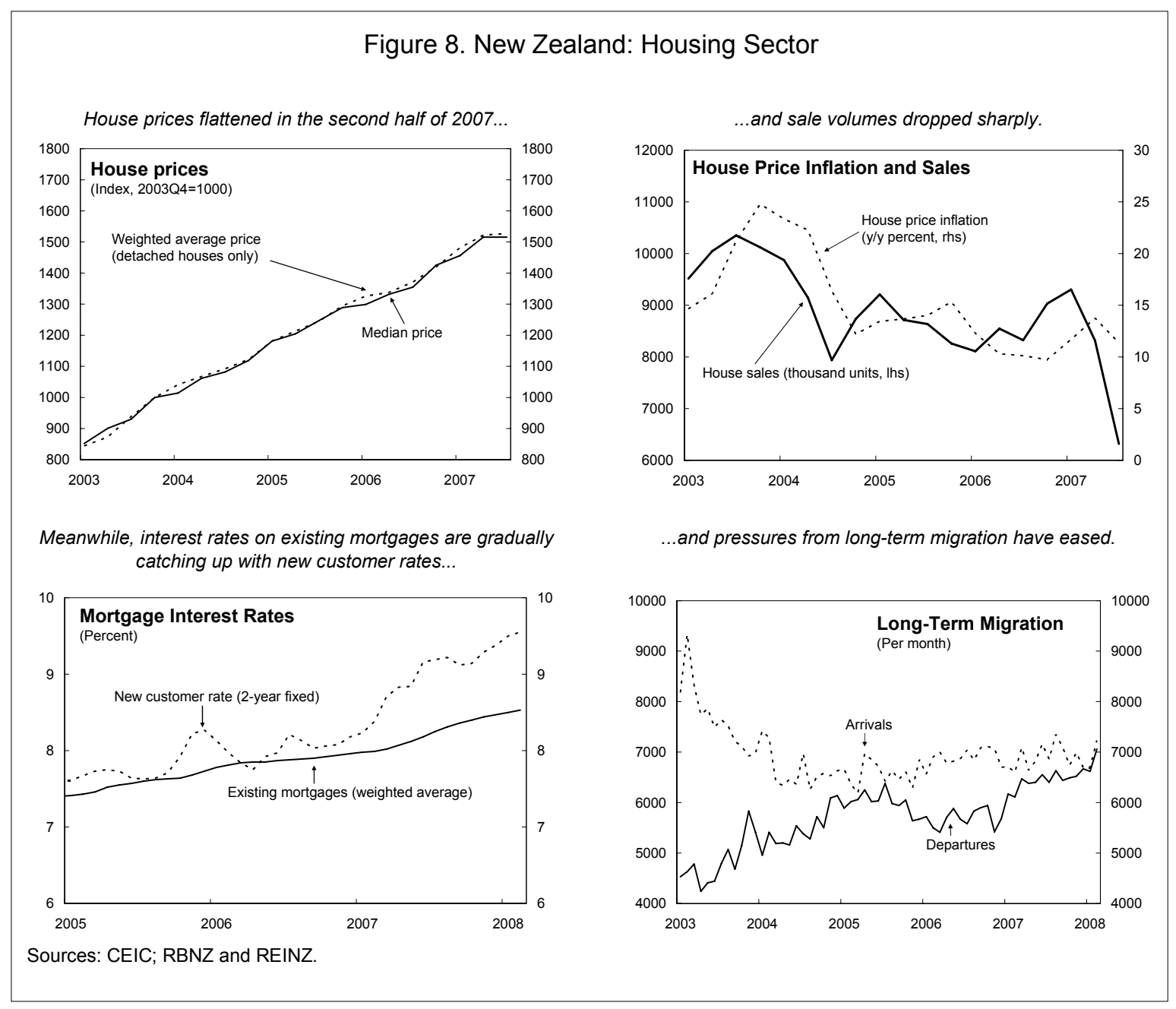

\section{Competitiveness and External Stability}

\section{The staff and authorities consider that the overvaluation of the New Zealand}

dollar primarily reflects temporary factors. The authorities' assess that the currency overvaluation is at the upper end of the staff's estimate of 5-15 percent (Box 2). Much of the overvaluation arises from a wide interest rate differential that resulted in large capital inflows. The authorities noted that over the past year the response to the differential had been muted. The staff and the authorities expected that the overvaluation would unwind over time as inflation abated and the policy interest rate could be reduced. However, the equilibrium level of the currency is likely to remain above its historical average because a portion of the rise in commodities prices will likely be permanent. ${ }^{4}$

\footnotetext{
${ }^{4}$ A selected issues paper analyzes the impact of higher commodity prices on the exchange rate.
} 


\section{Box 2. New Zealand's Equilibrium Real Exchange Rate}

Staff estimates suggest that the New Zealand dollar is overvalued by 5-15 percent. ${ }^{1}$ These estimates are based on the macroeconomic balance (MB) approach, the equilibrium real exchange rate (ERER) approach, and the external sustainability (ES) approach.

\section{The baseline MB estimates suggest an} overvaluation of 6-10 percent. $^{2}$ But the estimates are subject to uncertainty, as shown by varying the projection for the underlying current account deficit and changing the assumption for the elasticity of the current account balance with respect to the exchange rate. This sensitivity analysis suggests that the overvaluation is in the range of 5-24 percent.

\section{The baseline ERER estimates suggest an} overvaluation of 12-15 percent. The models attempt to explain the exchange rate based on the terms of trade, relative productivity, and relative government consumption. An important determinant is the terms of trade, with the 14 percent improvement in the terms of trade over the past five years contributing to an increase in the equilibrium REER of about 5 percent.

\section{The ES approach implies an overvaluation of} 11 percent, if we assume that net foreign liabilities stabilize at their average level for the past 10 years of 82 percent of GDP. A smaller overvaluation would result if we assume net foreign liabilities stabilize at the end 2007 level of 87 percent of GDP.

\begin{tabular}{|c|c|c|c|}
\hline \multicolumn{4}{|c|}{ Exchange Rate Assessment: Baseline Results 1/ } \\
\hline & \multicolumn{2}{|c|}{ CA/GDP } & \multirow{2}{*}{$\begin{array}{c}\text { REER } \\
\text { Overvaluation }\end{array}$} \\
\hline & Norm & Projection ${ }^{5 /}$ & \\
\hline \multicolumn{4}{|l|}{ MB Approach: ${ }^{2 /}$} \\
\hline CGER Methodology & -5.3 & -6.8 & 6.5 \\
\hline Desk & -4.4 & -6.8 & 10.5 \\
\hline \multicolumn{4}{|l|}{ ERER Approach: ${ }^{3 /}$} \\
\hline CGER Methodology & $\cdots$ & $\cdots$ & 14.5 \\
\hline Desk & $\ldots$ & $\ldots$ & 12.2 \\
\hline \multicolumn{4}{|l|}{ ES Approach: ${ }^{4 /}$} \\
\hline Desk & -4.2 & -6.8 & 11.3 \\
\hline \multicolumn{4}{|c|}{$\begin{array}{l}\text { Source: Fund staff estimates. } \\
\text { 1/ All numbers are expressed in percent. } \\
\text { 2/ Based on a semi-elasticity of the CA/GDP with respect to the REER of }-0.23 \\
\text { 3/ Overvaluation is assessed relative to December } 2007 \text {. } \\
\text { 4/ Based on a nominal GDP growth rate of } 5.4 \text { percent for the projection period. } \\
\text { 5/ WEO projection of the underlying CA/GDP in } 2013 \text {. }\end{array}$} \\
\hline
\end{tabular}

\begin{tabular}{|lccc|}
\hline \multicolumn{4}{c}{ MB Approach: Sensitivity Analysis 1/ } \\
\hline \multicolumn{4}{c}{ CA/GDP Projection ${ }^{21}$} \\
\cline { 2 - 4 } Elasticity & -6.0 & -6.8 & -8.0 \\
\hline-0.15 & 10.7 & 16.0 & 24.0 \\
-0.23 & 7.0 & 10.5 & 15.7 \\
-0.30 & 5.3 & 8.0 & 12.0 \\
\hline Source: Fund staff estimates. \\
1/ REER overvaluation is expressed in percent. \\
2/ WEO projection of the underlying CA/GDP in 2013. \\
\hline
\end{tabular}

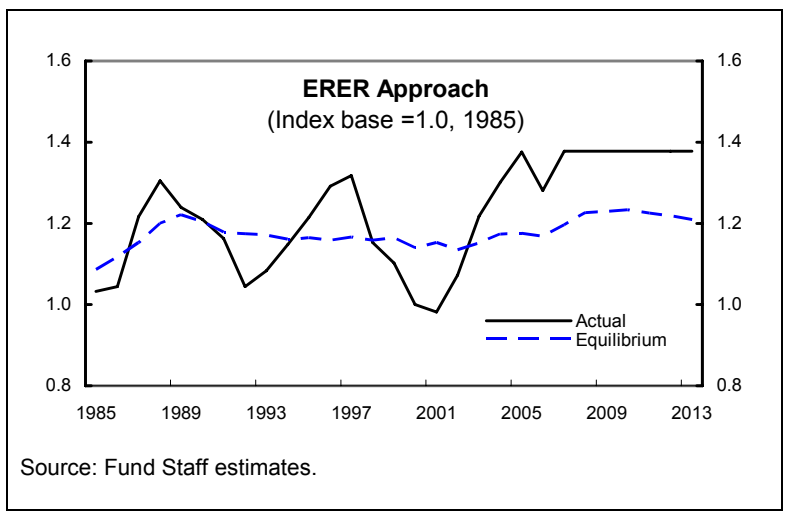

\footnotetext{
${ }^{1}$ The corresponding range for the equilibrium value of the RBNZ's real trade weighted index (TWI) is 63 to 70 , assessed relative to the December 2007 level of 74.3.

${ }^{2}$ For both the MB and ERER approaches, the CGER methodology applies the OLS estimation technique over the period 1970-2004. The desk methodology is outlined in Appendix I.
} 
14. The exchange rate could fall sharply if there were a disruption in capital inflows arising from the global financial market turmoil. The RBNZ was concerned that a sharp depreciation would boost inflation. While acknowledging that a depreciation would affect tradable goods inflation, the staff noted that a disruption to capital inflows would most likely slow domestic demand because of tighter credit conditions. In turn, this would reduce underlying inflationary pressures and might leave scope for the RBNZ to ease monetary policy. In these circumstances, fiscal policy could provide support through the operation of automatic stabilizers.

\section{A number of exporters were concerned that the currency overvaluation is} damaging the tradable goods sector. Although the magnitude of the exchange rate appreciation has been large, staff analysis suggests that it has not hurt tradable goods manufacturing significantly. ${ }^{5}$ The authorities noted that this could reflect the stability of the cross rate with Australia, its most important trading partner for manufactures.

\section{The RBNZ considered that their foreign exchange market intervention in mid-} 2007 achieved its intended objective. They believed that their selling of New Zealand dollars introduced some two-sided risk that helped relieve some temporary and unwarranted upward pressure on the exchange rate.

\section{Fiscal Policy}

17. The authorities' strategy is to transition to lower budget surpluses over time, conditional on the state of the economy. The government plans to reduce the surplus from $3 \frac{1}{2}$ percent of GDP in 2007/08 to less than 2 percent of GDP over the medium-term (Figure 9). As a result, the fiscal impulse is expected to be expansionary in 2008/09 with the stimulus abating thereafter. This plan includes a conditional allowance of 0.8 percent of GDP for personal income tax cuts together with increased spending. The Minister of Finance has stated publicly that the scope and shape of personal tax cuts would be such that they do not exacerbate inflationary pressures, increase public borrowing, or require a cut in public services. In line with previous Fund advice, the stimulus emphasizes tax cuts rather than spending increases, to limit pressure on resources. In addition, spending plans focus on improving productive capacity by addressing infrastructure bottlenecks. However, in recent years, the stimulus projected in the budget has not materialized because of stronger-thanexpected revenue growth.

\footnotetext{
${ }^{5}$ A selected issues paper uses the IMF's Global Economy Model to analyze this issue.
} 


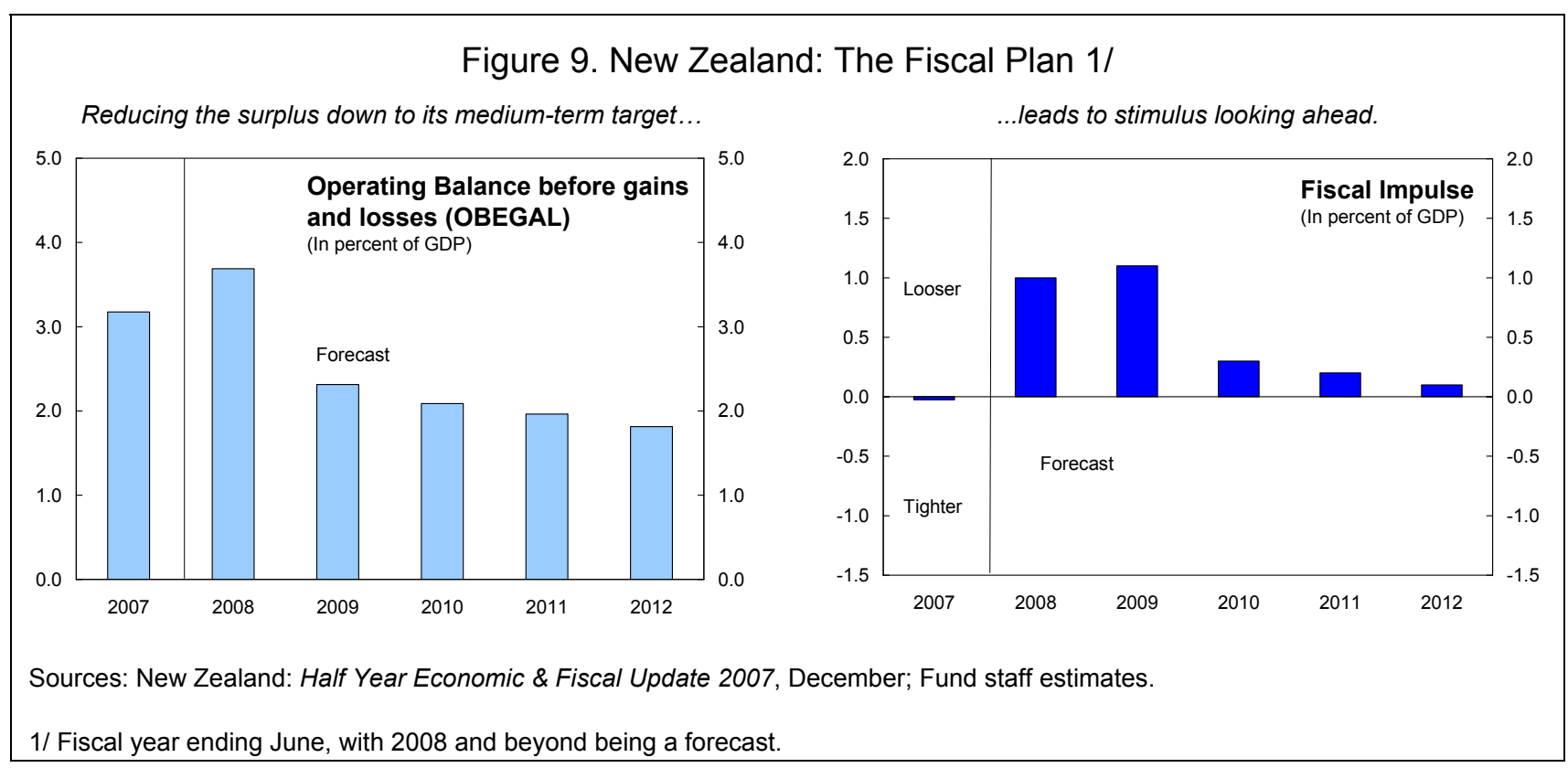

18. The staff endorsed the authorities' fiscal strategy, including the transition to a lower surplus, but stressed the need for caution in the near term. Staff pointed to uncertainty regarding the durability of higher corporate tax revenues, and noted it would be prudent to delay spending the revenue surprises which have added to surpluses in recent years until it was clear that they were structural. Therefore, the staff encouraged the authorities to maintain flexibility in the magnitude and the timing of the easing so that the fiscal stimulus will not occur until inflation pressures are expected to have abated and it is clear that fiscal resources exist to deliver the tax and spending measures.

19. The authorities recognized the need for fiscal policy to support monetary policy, but considered that the supply side benefits of lower income taxes and improved infrastructure were also important. Nonetheless, they acknowledged the downside risks to revenue if the economy slows more than expected. Therefore, delaying the tax cuts somewhat and perhaps scaling them down remain under consideration. They added that further tax cuts may be phased in over the medium-term once it was clear that revenue gains in recent years are permanent.

20. The authorities saw some merit in staff's advice to save revenue surprises until they can reasonably be determined to be structural. Staff noted that pre-announcing the intention to save surprises could help deflect political pressures for additional spending or tax cuts in the near-term that work against the operation of the automatic stabilizers.

\section{E. Financial Sector}

21. The large external refinancing needs of banks are a source of vulnerability. Onethird of banks' funding comes from nonresidents, of which two-thirds matures in one year or less. While banks' external debt is hedged against currency movements, the tightening in 
international credit markets has increased funding costs and highlighted rollover risk. ${ }^{6}$ Banks have contingency plans to deal with potential liquidity difficulties and are lengthening the maturity of their funding and diversifying the sources. ${ }^{7}$ In addition, the RBNZ is looking at instituting new liquidity guidelines for banks in late 2008 but no decision on the nature of the guidelines has been taken as yet, given the ongoing consultations with interested parties. The higher cost of medium-term funding compared with short-term funding is an obstacle to lengthening the maturity of funding. ${ }^{8}$ However, banks have been able to pass on some of the higher costs to borrowers, which limits the impact on bank profits.

\section{The RBNZ's action in late 2007 to provide additional domestic liquidity helped} ease pressures in money markets. Owing to continued unsettled conditions in global markets, the staff suggested that the RBNZ prepare a contingency plan to provide additional domestic liquidity in case of further disruption of New Zealand banks' access to liquidity.

\section{Banks are exposed to mortgages, but the RBNZ considered that they could} withstand sizable adverse shocks. Most conventional metrics indicate a modest degree of house price overvaluation (Box 3). However, the authorities pointed to factors that suggested banks' asset quality would not deteriorate seriously in the event of a correction in house prices. First, sub-prime mortgage lending, securitization, and off-balance sheet credit provision are very limited. Second, average loan-to-value ratios remain low at around 60 percent at end-2007. Third, a large portion of the debt is held by high-income groups. ${ }^{9}$ The authorities noted that for mortgage asset quality to deteriorate significantly, house prices would need to decline sharply, combined with sizable adverse shocks to unemployment and debt servicing costs.

\footnotetext{
${ }^{6}$ A selected issues paper examines the impact of a disruption in capital inflows.

${ }^{7}$ The four major banks accredited to use internal models under Basel II assess the impact of changes in funding costs as part of their stress tests. However, the banks are not required to hold regulatory capital against these risks. The RBNZ intends to review banks' experience with modeling this risk by early 2009 .

${ }^{8}$ For the four large Australasian banks, the 5-year credit default swap rate (CDS) averaged 126 basis points in March 2008 compared with 76 basis points for the 1-year credit default swap rate. The CDS rates, however, are not an accurate measure of the actual cost of funding.

${ }^{9}$ Households in the top two income quintiles held 72 percent of the debt identified in a 2004 household survey, while households in the bottom two income quintiles held just 8 percent of the debt, and had the lowest debt-toasset ratios (less than 25 percent). Results from the 2007 survey are not yet available.
} 


\section{Box 3. How Overvalued are New Zealand House Prices?}

House prices in New Zealand increased on average by 15 percent per annum during 2003-07. As a result, the ratio of house prices to average household incomes and the ratio of house prices to rents have increased substantially, and it would take a 40 percent fall in house prices to bring them back to historical averages. In addition, a Fitch Ratings study notes that New Zealand house prices are now the fourth most overvalued in a sample of 16 advanced countries, with France, the United Kingdom, and Denmark registering greater overvaluation.

Staff estimated a model of house price inflation for New Zealand, based on the extended version of Terrones (2004). ${ }^{1}$ The model uses an updated data set, and substitutes more appropriate New Zealand-specific variables for those used in earlier cross-country studies (in particular, migration is used instead of population growth, and a mortgage rate is used instead of a short-term interest rate). Estimation results show that 60 percent of variation in house price inflation in New Zealand can be explained by changes in interest rates and migration. Other variables that are typically important in other countries (such as affordability of houses, growth of real incomes, real credit growth, and stock prices) are not statistically significant in New Zealand. In 2003-07, house prices grew by a cumulative 90 percent, exceeding the model's prediction of 70 percent growth. This implies that house prices were overvalued by about 12 percent in the third quarter of 2007.

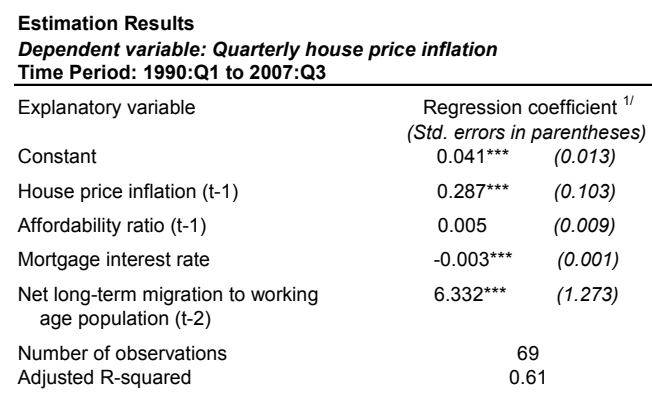

Regression coefficient ${ }^{1 /}$ (Std. errors in parenthese $0.041^{* * *} \quad(0.013)$

$0.287^{* * *} \quad(0.103)$

$0.005 \quad(0.009)$

$-0.003^{* * *} \quad(0.001)$

$6.332^{* * *} \quad(1.273)$

0.61

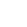

(20)

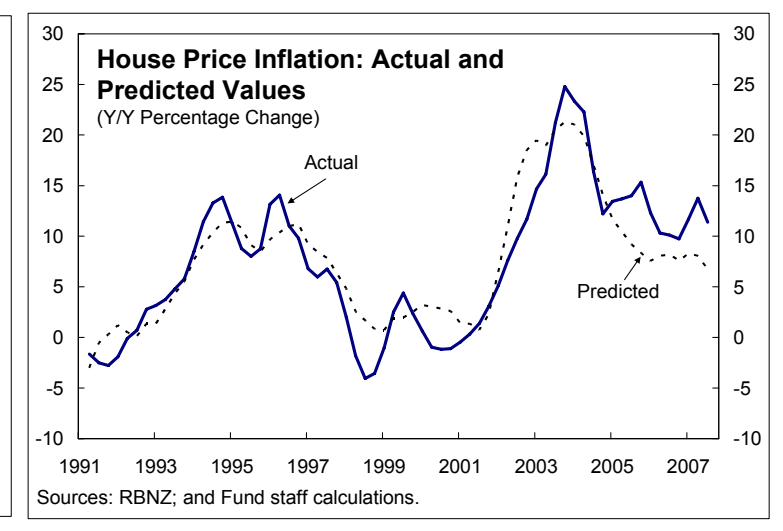

\footnotetext{
${ }^{1}$ See October 2007 World Economic Outlook.
} 
24. Good progress has been made on implementing Basel II. The four large banks have been accredited to use internal models to assess credit risk and the RBNZ is working closely with these banks to improve their models, particularly those related to housing and agriculture loans. In the meantime, banks must maintain capital at no less than 90 percent of what would be required under Basel I.

25. The authorities outlined a range of measures to strengthen oversight of nonbank financial institutions. The RBNZ will take over regulation of nonbank deposit takers in 2009, setting requirements for such things as governance, risk management, and licensing. The Securities Commission will approve and monitor the trustees which supervise these institutions. The Securities Commission is also tightening oversight of financial advisors and investment funds and insurance companies will come under the regulation and supervision of the RBNZ in 2010.

\section{Staff Appraisal}

26. Sound macroeconomic policies and structural reforms have resulted in $\mathbf{1 0}$ years of robust economic expansion. However, capacity constraints have emerged in recent years and inflation pressures have increased, especially with the rise in world commodity prices. Current policy settings and external prospects appear poised to deliver the required easing of constraints.

27. The current stance of monetary policy is appropriate. During 2007, retail mortgage rates became more responsive to the official cash rate, and this is having the desired effect of moderating house price inflation and slowing overall activity. More recently, tightening international credit conditions have also contributed to mortgage rate increases that should help ease capacity pressures. With significant risks present, monetary policy should remain on hold pending clearer indications of the future path of the economy.

28. Although inflows of foreign capital, attracted by wide interest rate differentials, have contributed to the appreciation of the currency, the strength in commodity prices has also been an important factor. As inflation pressures moderate and the policy rate normalizes, capital inflows are expected to ease and the exchange rate depreciate. However, the equilibrium level of the REER is likely to remain above its historical average because a portion of the rise in commodities prices will likely be permanent.

\section{A reduction in budget surpluses over time is consistent with prudent fiscal} policy, but caution is needed in the near term to avoid potentially adding to inflationary pressures. The focus of fiscal policy on sound medium-term objectives has delivered low public debt and a positive net financial asset position. With surpluses still in excess of the level required within the medium-term framework, the authorities' broad strategy for a gradual transition to a lower surplus, conditional on the state of the economy, is appropriate. Flexibility should be maintained in the magnitude and the timing of the easing so that the 
fiscal stimulus will not occur until inflation pressures are expected to have abated and it is clear that fiscal resources exist to deliver tax and spending measures.

30. The financial sector remains sound but vulnerabilities exist. Banks are profitable, well capitalized, and asset quality appears to be high. However, banks' assets are concentrated in residential mortgages, and banks have significant short-term international wholesale funding. The current tightening in international capital markets is putting upward pressure on bank funding costs and highlighting rollover risks.

\section{The vulnerabilities in the banking sector present some policy challenges. A}

further disruption to capital inflows that raises demand for domestic liquidity would need to be accommodated by the RBNZ. In addition, steps taken by the RBNZ to develop and implement guidelines aimed at improving banks' liquidity management are welcome. These guidelines should encourage banks to diversify funding sources as well as lengthen maturities to help reduce the risk of restricted access to funding.

32. Staff recommends the next Article IV consultation be on the standard 12-month cycle. 
Table 1. New Zealand: Selected Economic and Financial Indicators, 2004-09

Nominal GDP (2007): $\quad$ US\$128.6 billion

Population (2007): $\quad 4.3$ million

GDP per capita (2007): $\quad$ US $\$ 30,245$

Quota: SDR 894.6 million

\begin{tabular}{|c|c|c|c|c|c|c|}
\hline & 2004 & 2005 & 2006 & 2007 & $\begin{array}{c}2008 \\
\text { Proj. }\end{array}$ & $\begin{array}{c}2009 \\
\text { Proj. }\end{array}$ \\
\hline \multicolumn{7}{|l|}{ Real growth (percent change) } \\
\hline GDP (production basis) & 4.4 & 2.7 & 1.5 & 3.1 & 2.0 & 2.1 \\
\hline Final domestic demand & 7.2 & 4.6 & 1.9 & 4.5 & 2.7 & 2.0 \\
\hline Private consumption & 6.1 & 5.0 & 2.4 & 4.3 & 1.7 & 1.6 \\
\hline Government consumption & 5.4 & 4.2 & 5.0 & 4.0 & 3.0 & 2.3 \\
\hline Fixed investment & 11.2 & 4.0 & -1.3 & 5.4 & 5.0 & 2.6 \\
\hline Inventories $1 /$ & 0.3 & -0.3 & -0.9 & 0.5 & -0.9 & 0.0 \\
\hline Exports of goods and services & 5.9 & -0.4 & 1.8 & 3.5 & 5.4 & 4.0 \\
\hline Imports of goods and services & 16.0 & 5.4 & -2.7 & 8.8 & 5.9 & 3.5 \\
\hline Headline CPI inflation (percent change) & 2.3 & 3.0 & 3.4 & 2.4 & 3.4 & 2.7 \\
\hline End of period (percent change) & 2.7 & 3.2 & 2.7 & 3.2 & 3.1 & 2.5 \\
\hline Unemployment rate (in percent) & 3.9 & 3.7 & 3.8 & 3.6 & 3.9 & 4.3 \\
\hline \multicolumn{7}{|l|}{ Investment and saving (in percent of GDP) } \\
\hline Investment & 24.6 & 24.5 & 23.1 & 23.6 & 21.9 & 21.7 \\
\hline National saving $2 /$ & 18.2 & 16.0 & 14.5 & 15.7 & 14.8 & 14.4 \\
\hline \multicolumn{7}{|l|}{ Public finance (in percent of GDP) 3/ } \\
\hline Revenue & 32.9 & 34.4 & 37.5 & 34.6 & 35.0 & 34.0 \\
\hline Expenditure & 29.1 & 30.5 & 31.6 & 32.1 & 32.1 & 32.4 \\
\hline Operating balance $4 /$ & 5.2 & 4.1 & 7.3 & 4.8 & 4.1 & 3.2 \\
\hline Operating balance before gains and losses & 3.9 & 4.7 & 4.5 & 3.2 & 3.7 & 2.3 \\
\hline Net Crown debt including NZS Fund & 7.3 & 2.8 & -1.3 & -5.1 & -7.9 & -9.5 \\
\hline \multicolumn{7}{|l|}{ Money and credit (end of period) } \\
\hline Resident M3 (percent change) & 3.5 & 9.4 & 11.3 & 11.1 & $\ldots$ & $\ldots$ \\
\hline Private domestic credit (percent change) & 12.2 & 10.2 & 12.4 & 12.8 & $\ldots$ & $\ldots$ \\
\hline Interest rate (90-day, in percent) $5 /$ & 6.8 & 7.7 & 7.7 & 8.9 & 8.9 & $\ldots$ \\
\hline Government bond yield ( 10 -year, in percent) $5 /$ & 6.0 & 5.7 & 5.9 & 6.4 & 6.4 & $\ldots$ \\
\hline \multicolumn{7}{|l|}{ Balance of payments (in percent of GDP) } \\
\hline Current account & -6.4 & -8.5 & -8.6 & -7.9 & -7.1 & -7.3 \\
\hline (In billions of New Zealand dollars) & -9.5 & -13.2 & -14.0 & -13.8 & -13.1 & -14.1 \\
\hline Trade balance (goods) & -1.4 & -2.4 & -1.9 & -1.3 & 0.7 & 0.9 \\
\hline Terms of trade (percent change) & 6.3 & 1.1 & 0.0 & 6.0 & 6.5 & 0.6 \\
\hline \multicolumn{7}{|l|}{ Foreign assets and liabilities ( $\$ N Z$ billion) } \\
\hline Net international investment position & -124.2 & -131.2 & -142.5 & -152.4 & -166.0 & -180.6 \\
\hline (In percent of GDP) & -84.0 & -84.8 & -87.9 & -87.2 & -90.0 & -93.4 \\
\hline Official reserves & 9.7 & 13.1 & 19.9 & 22.3 & $\ldots$ & $\ldots$ \\
\hline \multicolumn{7}{|l|}{ Exchange rate (period average) } \\
\hline US\$/\$NZ $5 /$ & 0.66 & 0.70 & 0.65 & 0.74 & 0.79 & $\ldots$ \\
\hline Trade-weighted index (June $1979=100) 5 /$ & 66.5 & 70.4 & 65.4 & 70.9 & 71.8 & $\ldots$ \\
\hline Nominal effective exchange rate $6 /$ & 128.1 & 134.3 & 123.8 & 133.0 & $\ldots$ & $\ldots$ \\
\hline Real effective exchange rate $6 /$ & 130.1 & 137.6 & 128.1 & 137.7 & $\ldots$ & $\ldots$ \\
\hline GDP (in billions of New Zealand dollars) & 147.8 & 154.8 & 162.2 & 174.7 & 184.3 & 193.4 \\
\hline
\end{tabular}

Sources: Data provided by the New Zealand authorities; and Fund staff estimates and projections.

$1 /$ Contribution in percent of GDP.

2/ Based on national accounts data.

$3 /$ Fiscal years ending June 30

4/ Equals revenue less expenditure plus net surplus of state-owned enterprises and Crown entities.

5/ Data for 2008 are as of end-March.

6/ IMF Information Notice System index $(1990=100)$. 
Table 2. New Zealand: Summary of Central Government Budget, 2003/04-2007/08 1/

\begin{tabular}{|c|c|c|c|c|c|c|}
\hline & $2003 / 04$ & $2004 / 05$ & $2005 / 06$ & $2006 / 07$ & $2006 / 07$ & $2007 / 08$ \\
\hline & & & & Old GAAP & New GAAP & \\
\hline & & (In & ions of $\mathrm{Nev}$ & Zealand doll & ars) & \\
\hline Revenue & 46.9 & 52.1 & 59.2 & 59.5 & 58.2 & 62.4 \\
\hline Tax revenue & 42.5 & 46.6 & 52.0 & 51.5 & 53.0 & 56.6 \\
\hline Direct taxation & 28.6 & 32.0 & 36.7 & 36.0 & 37.0 & 39.9 \\
\hline Indirect taxation & 14.0 & 14.7 & 15.2 & 15.5 & 16.0 & 16.7 \\
\hline Nontax revenue & 4.4 & 5.4 & 7.2 & 8.0 & 5.2 & 5.8 \\
\hline Expenditure & 41.6 & 46.2 & 49.9 & 53.8 & 54.0 & 57.1 \\
\hline Social security and welfare & 14.3 & 14.7 & 15.6 & 17.3 & 17.2 & 17.9 \\
\hline New Zealand Superannuation (NZS) & 5.9 & 6.1 & 6.4 & 6.8 & 6.8 & 7.3 \\
\hline Other & 8.4 & 8.6 & 9.2 & 10.5 & 10.4 & 10.6 \\
\hline Health & 8.1 & 8.8 & 9.5 & 10.5 & 10.4 & 11.5 \\
\hline Education & 7.6 & 7.9 & 9.9 & 9.1 & 9.3 & 9.9 \\
\hline Defense & 1.3 & 1.3 & 1.4 & 1.5 & 1.5 & 1.6 \\
\hline Finance costs & 2.3 & 2.3 & 2.4 & 2.6 & 2.3 & 2.8 \\
\hline Other & 9.4 & 12.5 & 12.5 & 14.3 & 14.8 & 15.1 \\
\hline Net surplus from SOEs and Crown entities & 2.1 & 0.4 & 2.2 & 0.9 & 1.5 & 1.2 \\
\hline Operating balance $2 /$ & 7.4 & 6.2 & 11.5 & 6.6 & 8.1 & 7.4 \\
\hline Operating balance before gains and losses & 5.6 & 7.1 & 7.1 & 5.3 & 5.3 & 6.6 \\
\hline Residual cash balance 3/ & 0.5 & 3.1 & 3.0 & 1.7 & 2.7 & 0.8 \\
\hline Gross sovereign-issued debt & 34.7 & 35.0 & 35.5 & 37.2 & 36.8 & 39.6 \\
\hline Net core Crown debt with NZS Fund & 10.4 & 4.2 & -2.1 & -8.3 & -8.6 & -14.0 \\
\hline Net worth $4 /$ & 35.5 & 50.0 & 71.4 & 88.5 & 96.7 & 104.3 \\
\hline & & & (In percer & t of GDP) & & \\
\hline Revenue & 32.9 & 34.4 & 37.5 & 35.4 & 34.6 & 35.0 \\
\hline Tax revenue & 29.8 & 30.8 & 32.9 & 30.7 & 31.5 & 31.8 \\
\hline Expenditure & 29.1 & 30.5 & 31.6 & 32.0 & 32.1 & 32.1 \\
\hline Social security and welfare & 10.0 & 9.7 & 9.9 & 10.3 & 10.2 & 10.1 \\
\hline Health & 5.7 & 5.8 & 6.1 & 6.2 & 6.2 & 6.4 \\
\hline Education & 5.3 & 5.2 & 6.3 & 5.4 & 5.5 & 5.5 \\
\hline Finance costs & 1.6 & 1.5 & 1.5 & 1.5 & 1.4 & 1.6 \\
\hline Other & 6.6 & 8.3 & 7.9 & 8.5 & 8.8 & 8.5 \\
\hline Net surplus from SOEs and Crown entities & 1.5 & 0.3 & 1.4 & 0.5 & 0.9 & 0.7 \\
\hline Operating balance $2 /$ & 5.2 & 4.1 & 7.3 & 3.9 & 4.8 & 4.1 \\
\hline Operating balance before gains and losses & 3.9 & 4.7 & 4.5 & 3.2 & 3.2 & 3.7 \\
\hline Residual cash balance 3 / & 0.4 & 2.1 & 1.9 & 1.0 & 1.6 & 0.4 \\
\hline Gross sovereign-issued debt & 24.3 & 23.1 & 22.5 & 22.1 & 21.9 & 22.2 \\
\hline Net core Crown debt with NZS Fund & 7.3 & 2.8 & -1.3 & -4.9 & -5.1 & -7.9 \\
\hline Net worth $4 /$ & 24.8 & 33.0 & 45.3 & 52.6 & 57.5 & 58.5 \\
\hline Memorandum item (in billions of NZ dollars) & & & & & & \\
\hline Contributions to NZS Fund & 1.9 & 2.1 & 2.3 & 2.0 & 2.0 & 2.1 \\
\hline NZS Fund balance & 4.0 & 6.6 & 9.9 & 12.9 & 13.0 & 16.0 \\
\hline
\end{tabular}

Sources: New Zealand Treasury; HYEFU (Half Year Economic and Fiscal Update, 2007).

1/ Fiscal year ending June 30. From 2006/07, accounts follow the new version of New Zealand Generally Accepted Accounting Practices. 2/ Equals revenue less expenditure plus net surplus of state-owned enterprises and Crown entities.

3/ Net core Crown cashflow from operations after contributions to NZS Fund, purchases of physcial assets, and advances and capital injections.

4/ Includes financial assets of the NZS Fund. 
Table 3. New Zealand: Balance of Payments and External Debt, 2003-08

\begin{tabular}{|c|c|c|c|c|c|c|}
\hline & 2003 & 2004 & 2005 & 2006 & 2007 & $\begin{array}{c}2008 \\
\text { Proj. }\end{array}$ \\
\hline & \multicolumn{6}{|c|}{ (In percent of GDP) } \\
\hline Current account balance & -4.3 & -6.4 & -8.5 & -8.6 & -7.9 & -7.1 \\
\hline Goods balance & -0.6 & -1.4 & -2.4 & -1.9 & -1.3 & 0.7 \\
\hline Exports, f.o.b. & 21.1 & 20.9 & 20.2 & 21.5 & 21.3 & 23.5 \\
\hline Imports, f.o.b. & -21.7 & -22.3 & -22.6 & -23.3 & -22.6 & -22.9 \\
\hline Services balance & 1.4 & 0.9 & 0.3 & 0.3 & 0.2 & 0.2 \\
\hline Receipts & 8.6 & 8.3 & 7.9 & 7.7 & 7.2 & 7.1 \\
\hline Payments & -7.2 & -7.3 & -7.6 & -7.4 & -7.0 & -6.8 \\
\hline Income balance & -5.2 & -6.1 & -6.8 & -7.4 & -7.2 & -8.4 \\
\hline Receipts & 1.8 & 1.6 & 1.3 & 1.4 & 2.1 & 1.7 \\
\hline Payments & -7.0 & -7.6 & -8.2 & -8.7 & -9.3 & -10.2 \\
\hline Transfers balance & 0.2 & 0.1 & 0.3 & 0.4 & 0.3 & 0.4 \\
\hline Inflows & 1.1 & 0.9 & 1.1 & 1.2 & 1.1 & 1.1 \\
\hline Outflows & -0.9 & -0.8 & -0.8 & -0.8 & -0.8 & -0.7 \\
\hline Capital and financial account balance & 3.8 & 7.8 & 7.8 & 8.1 & 7.6 & $\ldots$ \\
\hline Capital account (net) & 0.6 & 0.2 & -0.2 & -0.2 & -0.4 & $\ldots$ \\
\hline Financial account (net) & 3.2 & 7.7 & 8.0 & 8.3 & 8.0 & $\ldots$ \\
\hline Direct investment (net) & 2.0 & 3.1 & 2.9 & 7.3 & 0.0 & $\ldots$ \\
\hline Portfolio investment (net) & 1.4 & 6.1 & -0.2 & -1.6 & 8.7 & $\ldots$ \\
\hline Equity securities (net) & -0.2 & -1.5 & -1.2 & -1.0 & -0.5 & $\ldots$ \\
\hline Debt securities (net) & 1.6 & 7.5 & 1.0 & -0.6 & 9.2 & $\ldots$ \\
\hline Other investment (net) & -0.2 & -1.5 & 5.2 & 2.6 & -0.7 & $\ldots$ \\
\hline Assets & -1.0 & -0.2 & 1.6 & -5.3 & -4.2 & $\ldots$ \\
\hline Liabilities & 0.8 & -1.3 & 3.6 & 7.9 & 3.4 & $\ldots$ \\
\hline Net errors and omissions & 0.4 & -1.4 & 0.8 & 0.5 & 0.4 & $\ldots$ \\
\hline \multirow[t]{2}{*}{ Overall balance } & 0.0 & 0.0 & 0.0 & 0.0 & 0.0 & $\ldots$ \\
\hline & \multicolumn{6}{|c|}{ (Assets and liabilities as of end-December) } \\
\hline Total external debt & 103.8 & 107.3 & 106.3 & 115.1 & 119.9 & 122.0 \\
\hline Short-term & 48.5 & 53.4 & 55.1 & 59.4 & 65.2 & $\ldots$ \\
\hline Long-term & 55.3 & 53.9 & 51.1 & 55.7 & 54.7 & $\ldots$ \\
\hline Net international investment position & -77.5 & -84.0 & -84.8 & -87.9 & -87.2 & -90.0 \\
\hline Net equity & -16.2 & -17.1 & -13.1 & -12.5 & -10.5 & $\ldots$ \\
\hline \multirow[t]{2}{*}{ Net debt } & -61.3 & -66.9 & -71.6 & -75.4 & -76.8 & $\ldots$ \\
\hline & \multicolumn{6}{|c|}{ (In billions of New Zealand dollars) } \\
\hline Gross official reserves $1 /$ & 9.3 & 9.7 & 13.1 & 19.9 & 22.3 & 22.1 \\
\hline RBNZ net short position in forex swaps $1 /$ & $\ldots$ & 1.5 & 2.7 & 10.5 & 10.3 & 10.5 \\
\hline RBNZ net open foreign currency position $1 /$ & $\ldots$ & 0.0 & 0.0 & -0.1 & 2.5 & 2.9 \\
\hline Gross reserves in months of future imports of g\&s & 3.8 & 3.9 & 5.1 & 8.1 & 9.0 & 9.1 \\
\hline Gross reserves as percent of short-term debt & 14.0 & 12.3 & 15.3 & 20.7 & 19.6 & 18.1 \\
\hline
\end{tabular}

Sources: Data provided by the New Zealand authorities; and Fund staff estimates.

1/ For 2008, actual number for end-February. 
Table 4. New Zealand: Medium-Term Scenario, 2007-13

\begin{tabular}{|c|c|c|c|c|c|c|c|c|}
\hline & \multicolumn{2}{|l|}{ Average } & \multicolumn{6}{|c|}{ Projections } \\
\hline & $1 \overline{997-2006}$ & $2007^{-}$ & 2008 & 2009 & 2010 & 2011 & 2012 & 2013 \\
\hline \multicolumn{9}{|l|}{ Real growth (percent change) } \\
\hline GDP (production basis) & 3.0 & 3.1 & 2.0 & 2.1 & 2.7 & 2.7 & 2.8 & 2.9 \\
\hline Final domestic demand & 3.8 & 4.5 & 2.7 & 2.0 & 2.3 & 2.6 & 2.8 & 2.9 \\
\hline Consumption & 3.6 & 4.3 & 2.0 & 1.8 & 2.1 & 2.4 & 2.5 & 2.7 \\
\hline Private consumption & 3.7 & 4.3 & 1.7 & 1.6 & 1.9 & 2.3 & 2.3 & 2.6 \\
\hline Government consumption & 3.4 & 4.0 & 3.0 & 2.3 & 2.8 & 3.0 & 3.0 & 2.8 \\
\hline Fixed investment & 4.6 & 5.4 & 5.0 & 2.6 & 3.1 & 3.2 & 3.5 & 3.6 \\
\hline Inventories $1 /$ & -0.1 & 0.5 & -0.9 & 0.0 & 0.4 & 0.0 & 0.0 & 0.0 \\
\hline Exports of goods and services & 4.0 & 3.5 & 5.4 & 4.0 & 4.2 & 4.3 & 4.4 & 4.5 \\
\hline Imports of goods and services & 5.4 & 8.8 & 5.9 & 3.5 & 3.9 & 4.0 & 4.1 & 4.3 \\
\hline \multicolumn{9}{|l|}{ Saving and investment (percent of GDP) } \\
\hline Gross capital formation & 22.6 & 23.6 & 21.9 & 21.7 & 22.7 & 22.8 & 22.7 & 22.6 \\
\hline Fixed investment & 21.7 & 23.1 & 23.1 & 22.8 & 22.3 & 22.4 & 22.3 & 22.3 \\
\hline Increase in stocks & 0.8 & 0.5 & -1.2 & -1.1 & 0.4 & 0.4 & 0.4 & 0.4 \\
\hline National saving $2 /$ & 17.0 & 15.7 & 14.8 & 14.4 & 15.7 & 15.7 & 15.7 & 15.6 \\
\hline Private & 13.8 & 11.7 & 11.4 & 11.4 & 12.8 & 13.0 & 13.4 & 13.6 \\
\hline Public & 3.2 & 4.0 & 3.4 & 3.0 & 2.9 & 2.7 & 2.2 & 2.0 \\
\hline \multicolumn{9}{|l|}{ Inflation and unemployment (percent) } \\
\hline Headline CPI inflation & 2.1 & 2.4 & 3.4 & 2.7 & 2.3 & 2.2 & 2.1 & 2.0 \\
\hline Unemployment rate & 5.3 & 3.6 & 3.9 & 4.3 & 4.5 & 4.5 & 4.5 & 4.5 \\
\hline \multicolumn{9}{|l|}{ Government budget (percent of GDP) 3/ } \\
\hline Revenue & 34.0 & 34.6 & 35.0 & 34.0 & 33.8 & 34.2 & 34.2 & 34.2 \\
\hline Expenditure & 31.9 & 32.1 & 32.1 & 32.4 & 32.4 & 32.8 & 33.1 & 33.1 \\
\hline SOE and Crown entity surplus (net) & 0.7 & 0.9 & 0.7 & 1.0 & 0.9 & 0.8 & 0.8 & 0.8 \\
\hline Operating balance $4 /$ & 2.9 & 4.8 & 4.1 & 3.2 & 3.0 & 3.0 & 2.8 & 2.1 \\
\hline Operating balance before gains and losses & 2.4 & 3.2 & 3.7 & 2.3 & 2.1 & 2.0 & 1.8 & 1.8 \\
\hline Gross Crown debt & 29.8 & 21.9 & 22.2 & 21.0 & 19.6 & 20.1 & 18.6 & 18.6 \\
\hline Net Crown debt including NZS Fund & $\ldots$ & -5.1 & -7.9 & -9.5 & -11.0 & -12.4 & -13.7 & -13.1 \\
\hline Net worth $5 /$ & $\ldots$ & 57.5 & 58.5 & 59.0 & 59.8 & 60.3 & 60.6 & 60.2 \\
\hline Terms of trade $(2002=100$, goods $)$ & 101.8 & 114.9 & 122.4 & 123.1 & 123.4 & 118.2 & 115.1 & 112.3 \\
\hline Terms of trade (percent change, goods) & 1.0 & 6.0 & 6.5 & 0.6 & 0.2 & -4.2 & -2.6 & -2.4 \\
\hline Export prices & 2.0 & 0.9 & 5.8 & 0.1 & -0.2 & -4.5 & -3.5 & -3.5 \\
\hline Import prices & 0.9 & -4.8 & -0.6 & -0.5 & -0.4 & -0.4 & -0.9 & -1.2 \\
\hline \multicolumn{9}{|l|}{ Balance of payments (percent of GDP) } \\
\hline Current account balance & -5.6 & -7.9 & -7.1 & -7.3 & -7.1 & -7.1 & -7.1 & -7.0 \\
\hline Balance on goods and services & 0.2 & -1.1 & 0.9 & 1.4 & 1.7 & 1.1 & 0.8 & 0.6 \\
\hline Balance on income and transfers & -5.8 & -6.9 & -8.0 & -8.7 & -8.8 & -8.2 & -7.9 & -7.7 \\
\hline Net foreign liabilities (percent of GDP) 6/ & 82.1 & 87.2 & 90.0 & 93.4 & 95.2 & 99.0 & 102.2 & 105.1 \\
\hline Gross external debt & 104.2 & 119.9 & 122.0 & 124.6 & 125.9 & 128.7 & 131.1 & 133.3 \\
\hline
\end{tabular}

Sources: Data provided by the New Zealand authorities; and Fund staff estimates and projections.

1/ Contribution in percent of GDP.

2/ Fund staff estimates; calculated as residual from gross national investment and external current account balance. $3 /$ Fiscal years ending June 30 .

4/ Equals revenue less expenditure plus net surplus of state-owned enterprises and Crown entities.

$5 /$ Includes the financial assets of the NZS Fund.

6/ Data for end-December. 
Figure 10. New Zealand: External Debt Sustainability: Bound Tests 1/ (Gross external debt in percent of GDP)
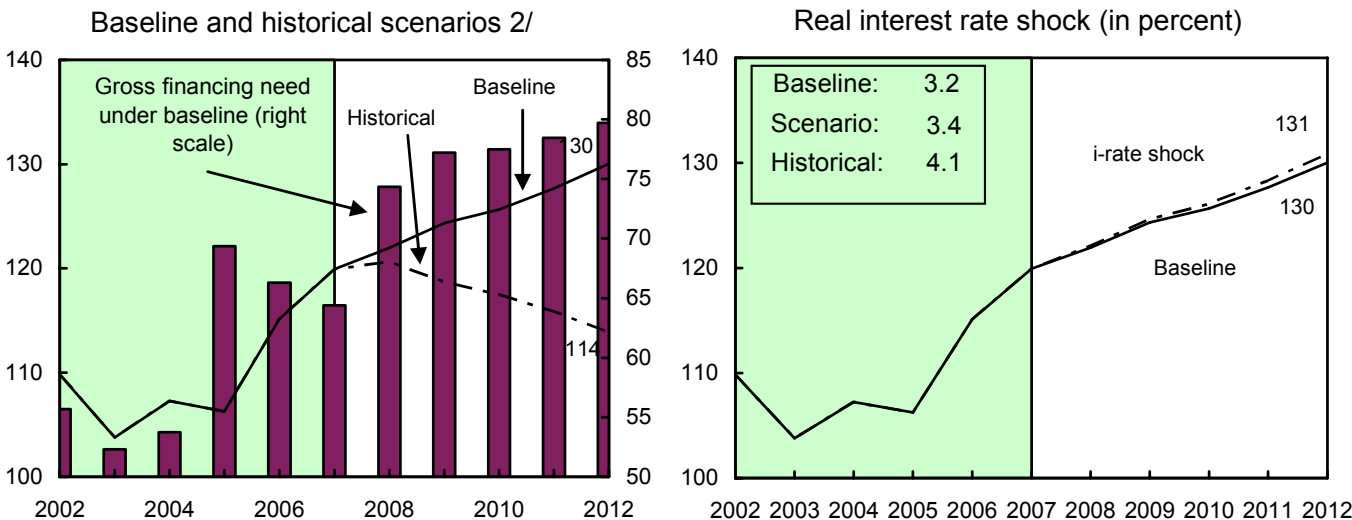

Growth shock (in percent per year)
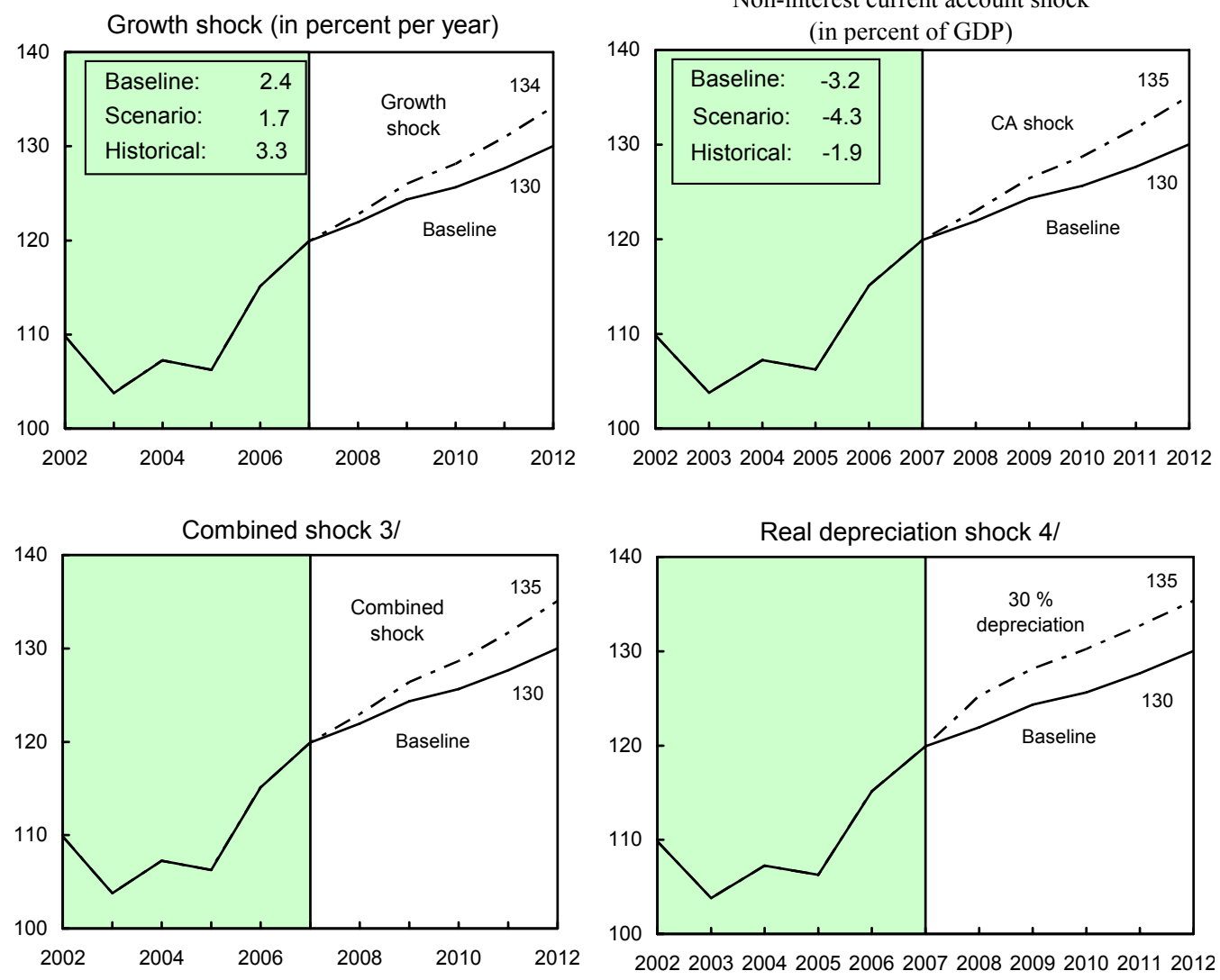

Sources: Fund staff estimates and projections.

1/ Shaded areas represent actual data. Individual shocks are permanent one-half standard deviation shocks. Figures in the boxes represent average projections for the respective variables in the baseline and scenario being presented. Ten-year historical average for the variable is also shown.

2/ The historical scenario assumes that real GDP growth, inflation, current account deficit, and nominal interest rate are equal to ten-year historical averages from 2008 onward.

$3 /$ Permanent 1/4 standard deviation shocks applied to interest rate, growth rate, and current account balance. 4/ This scenario assumes foreign exchange hedging covers 91 percent of foreign currency debt, consistent with the findings of hedging surveys conducted by Statistics New Zealand. 


\section{Appendix I. Exchange Rate Assessment Methodology}

The desk estimates of the equilibrium value of the REER for the macroeconomic balance (MB) and the equilibrium real exchange rate (ERER) approaches are based on panel econometric techniques using a generalized method of moments (GMM) estimator. To control for endogeneity, lagged explanatory variables are employed as instruments, where appropriate. The tables and figures below summarize the results. Further details are available in a forthcoming working paper.

\begin{tabular}{|lcc|}
\hline \multicolumn{3}{|c|}{ MB Estimation Results for 55 Economies, 1973-2007 } \\
\hline Dependent Variable: CA/GDP & Estimate & t Ratio \\
\hline & & \\
\hline Relative old age dependency & -0.70 & -5.02 \\
Relative population growth & -4.19 & -2.82 \\
Relative income growth & -0.45 & -2.08 \\
Oil trade balance & 0.78 & 5.68 \\
Initial net foreign assets & 0.001 & 2.44 \\
\hline & & \\
Observations & 838 & \\
R Squared & 0.52 \\
\hline
\end{tabular}

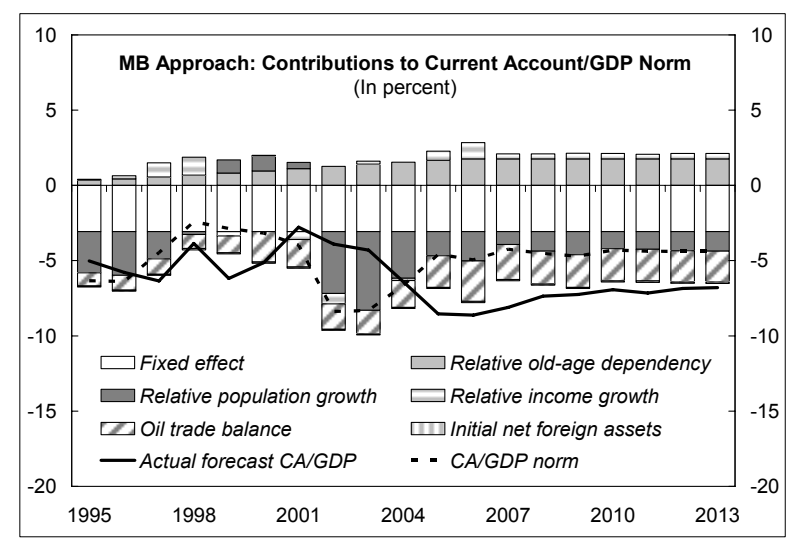

\begin{tabular}{|lcc|}
\hline \multicolumn{3}{|l|}{ ERER Estimation Results for 55 Economies, 1973-2007 } \\
\hline Dependent Variable: REER & Estimate & t Ratio \\
\hline & & \\
\hline Terms of trade & 0.36 & 3.78 \\
Relative productivity & 0.24 & 5.33 \\
Relative government & & \\
consumption & 1.58 & 4.05 \\
\hline $\begin{array}{l}\text { Observations } \\
\text { R Squared }\end{array}$ & 945 & \\
\hline
\end{tabular}

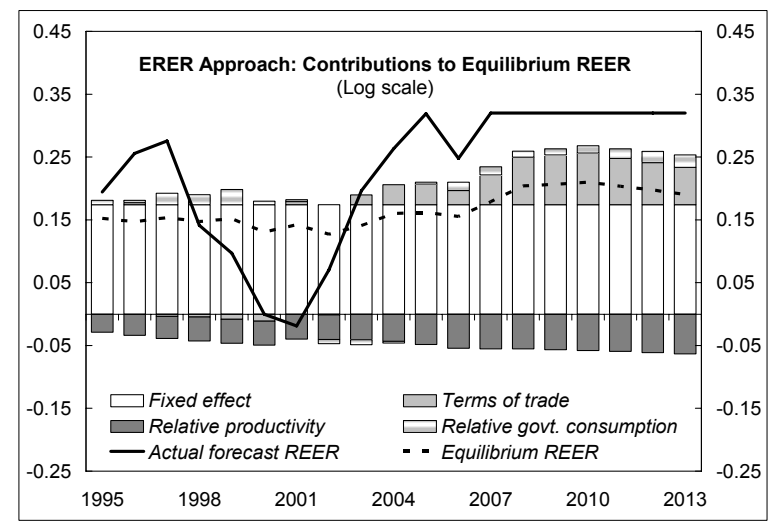




\title{
INTERNATIONAL MONETARY FUND
}

\author{
NEW ZEALAND \\ Staff Report for the 2008 Article IV Consultation-Informational Annex \\ Prepared by the Staff Representatives for the 2008 Consultation with New Zealand \\ (In Consultation with Other Departments)
}

April 17, 2008

Contents

Page

I. Fund Relations ...........................................................................................

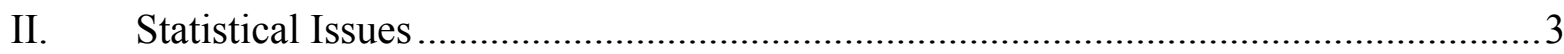


ANNEX I. NeW ZEALAND: FUND RELATIONS

(As of March 31, 2008)

I. Membership Status: Joined: August 31, 1961; Article VIII

II. General Resources Account:

SDR Million

Percent Quota

Quota

894.60

100.00

Fund Holdings of Currency

837.51

93.62

Reserve position in Fund

57.12

6.39

III. SDR Department:

SDR Million

141.32

Percent Allocation

Net cumulative allocation

16.97

100.00

Holdings

12.01

IV. Outstanding Purchases and Loans: None

V. Financial Arrangements: None

VI. Projected Obligations to Fund: None

VII. Exchange Arrangement:

New Zealand accepted the obligations of Article VIII on August 5, 1982. The New Zealand dollar has floated independently since March 1985. New Zealand maintains an exchange system that is free of restrictions on the making of payments and transfers for current international transactions, other than restrictions notified to the Fund in accordance with Decision No. 144-(52/51).

VIII. Article IV Consultation:

New Zealand is on the 12-month consultation cycle. The 2007 Article IV consultation discussions were held during February 12-21, 2007, the Executive Board discussed the staff report (IMF Country Report No. 07/150) and concluded the consultation on April 27, 2007.

IX. FSAP Participation and ROSCs:

FSAP mission took place during October 30-November 18, 2003. The FSSA and the Detailed Assessments of Observance of IOSCO Objectives and Principles of Securities Regulation and FATF Recommendations for Anti-Money Laundering and Combating the Financing of Terrorism were published under Country Reports No. 04/126, No. 04/417, and No. 05/284, respectively.

X. Technical Assistance: None

XI. Resident Representative/Advisor: None 


\section{ANNEX II. NeW ZEALAND: STATISTICAL IsSUES}

New Zealand publishes a wide array of high quality economic and financial data, which are fully adequate for surveillance purposes. The authorities are continuing to enhance data quality and expand the range of data products available, including a project led by the New Zealand Treasury to publish fiscal data consistent with the Government Finance Statistics Manual 2001 (GFSM 2001). The Reserve Bank of New Zealand has indicated that it is not at present in a position to submit the standardized report forms for monetary statistics introduced in October 2004. New Zealand has made progress toward becoming a subscriber to the Special Data Dissemination Standard (SDDS). The main remaining issues are the requirement for publication of an industrial production index, and the timeliness of local government data.

Table of Common Indicators Required for Surveillance (As of April 17, 2008)

\begin{tabular}{|c|c|c|c|c|c|}
\hline & $\begin{array}{c}\text { Date of } \\
\text { latest } \\
\text { observation }\end{array}$ & $\begin{array}{l}\text { Date } \\
\text { received }\end{array}$ & $\begin{array}{l}\text { Frequency } \\
\text { of } \\
\text { Data }^{6}\end{array}$ & $\begin{array}{l}\text { Frequency } \\
\text { of } \\
\text { Reporting }^{6}\end{array}$ & $\begin{array}{l}\text { Frequency } \\
\text { of } \\
\text { Publication }\end{array}$ \\
\hline Exchange Rates & $4 / 17 / 08$ & $4 / 17 / 08$ & $\mathrm{D}$ & $\mathrm{D}$ & $\mathrm{D}$ \\
\hline $\begin{array}{l}\text { International Reserve Assets and Reserve } \\
\text { Liabilities of the Monetary Authorities }{ }^{1}\end{array}$ & $02 / 08$ & $3 / 31 / 08$ & M & M & M \\
\hline Reserve/Base Money & $02 / 08$ & $3 / 31 / 08$ & M & M & M \\
\hline Broad Money & $02 / 08$ & $3 / 31 / 08$ & M & M & M \\
\hline Central Bank Balance Sheet & $02 / 08$ & $3 / 31 / 08$ & M & M & M \\
\hline $\begin{array}{l}\text { Consolidated Balance Sheet of the Banking } \\
\text { System }\end{array}$ & $02 / 08$ & $3 / 31 / 08$ & M & M & M \\
\hline Interest Rates ${ }^{2}$ & 4/17/08 & $4 / 17 / 08$ & $\mathrm{D}$ & $\mathrm{D}$ & $\mathrm{D}$ \\
\hline Consumer Price Index & Q1 2008 & $4 / 15 / 08$ & Q & Q & Q \\
\hline $\begin{array}{l}\text { Revenue, Expenditure, Balance and } \\
\text { Composition of Financing }^{3}-\text { General } \\
\text { Government }^{4}\end{array}$ & $2006 / 07$ & $10 / 10 / 07$ & A & A & NA \\
\hline $\begin{array}{l}\text { Revenue, Expenditure, Balance and } \\
\text { Composition of Financing }{ }^{3}-\text { Central Government }\end{array}$ & $02 / 08$ & $4 / 4 / 08$ & M & M & M \\
\hline $\begin{array}{l}\text { Stocks of Central Government and Central } \\
\text { Government-Guaranteed Debt }{ }^{5}\end{array}$ & $02 / 08$ & $4 / 4 / 08$ & M & M & M \\
\hline External Current Account Balance & Q4 2007 & $3 / 27 / 08$ & Q & Q & Q \\
\hline Exports and Imports of Goods and Services & Q4 2007 & $3 / 27 / 08$ & Q & Q & Q \\
\hline GDP/GNP & Q4 2007 & $3 / 28 / 08$ & Q & Q & $\mathrm{Q}$ \\
\hline Gross External Debt & Q4 2007 & $3 / 27 / 08$ & Q & Q & Q \\
\hline
\end{tabular}

${ }^{1}$ Includes reserve assets pledged or otherwise encumbered as well as net derivative positions.

${ }^{2}$ Both market-based and officially determined, including discount rates, money market rates, rates on treasury bills, notes, and bonds.

${ }^{3}$ Foreign, domestic bank, and domestic non-bank financing.

${ }^{4}$ The general government consists of the central government (including budgetary, extra budgetary, and social security funds) and state and local governments.

${ }^{5}$ Including currency and maturity composition.

${ }^{6}$ Daily (D), Weekly (W), Monthly (M), Quarterly (Q), Annually (A), Irregular (I); Not Available (NA). 


\section{INTERNATIONAL MONETARY FUND}

EXTERNAL

Public Information Notice

RELATIONS

DEPARTMENT

Public Information Notice (PIN) No. 08/56

FOR IMMEDIATE RELEASE

International Monetary Fund

May 19, 2008

$70019^{\text {th }}$ Street, NW

Washington, D. C. 20431 USA

\section{IMF Executive Board Concludes 2008 Article IV Consultation with New Zealand}

On May 9, 2008, the Executive Board of the International Monetary Fund (IMF) concluded the Article IV consultation with New Zealand. ${ }^{1}$

\section{Background}

New Zealand has experienced a decade-long economic expansion, but resource constraints have emerged in recent years with rising capacity utilization and unemployment falling to historical lows. This combined with rapidly appreciating house and share prices resulted in demand pressures increasing nontradables inflation. Domestic demand became increasingly satisfied with imports, widening the current account deficit to more than 8 percent of GDP. The large current account deficits increased net foreign liabilities to almost 90 percent of GDP, accumulating primarily as debt on banks' balance sheets.

In response to rising inflation, the Reserve Bank of New Zealand (RBNZ) raised the official cash rate from 5.0 percent in 2003 to its current level of 8.25 percent. However, competition in the mortgage market, in part reflecting banks' access to abundant international liquidity, slowed the transmission into mortgage rates. Searching for yield, international investors responded to the wide interest rate differential, and inflows of foreign capital appreciated the exchange rate.

\footnotetext{
${ }^{1}$ Under Article IV of the IMF's Articles of Agreement, the IMF holds bilateral discussions with members, usually every year. A staff team visits the country, collects economic and financial information, and discusses with officials the country's economic developments and policies. On return to headquarters, the staff prepares a report, which forms the basis for discussion by the Executive Board. At the conclusion of the discussion, the Managing Director, as Chairman of the Board, summarizes the views of Executive Directors, and this summary is transmitted to the country's authorities.
} 
The fiscal position has strengthened over the past several years. Large surpluses emerged as revenue outcomes consistently surprised on the upside, moving the public sector into a positive net financial asset position. However, the strong performance has increased pressures to bring the fiscal position more in line with the medium-term targets by cutting taxes and increasing spending.

The banking sector is sound, with stable profits, high capitalization, and few nonperforming loans, but vulnerabilities exist. On the liabilities side, the global financial market turmoil has increased funding costs and highlighted the rollover risk associated with banks' short-term debt. On the asset side, the large mortgage book leaves banks exposed to heavily indebted households.

\section{Executive Board Assessment}

Executive Directors commended the New Zealand authorities for their continued implementation of sound macroeconomic policies and structural reforms that have resulted in ten years of robust economic expansion. More recently, however, inflation has increased, the current account deficit has grown, and capacity constraints have emerged, presenting the authorities with challenges in the period ahead. Directors were confident that the authorities' current policy settings, supported by the anticipated evolution of external and global developments, will help to address these challenges.

Directors welcomed the focus of New Zealand's fiscal policy on sound medium-term objectives, which has delivered a low level of public debt and a positive net financial asset position. They agreed that, with surpluses in excess of the level required by the medium-term fiscal framework, the authorities' strategy of reducing the surplus gradually, if economic conditions permit, is appropriate. However, flexibility and caution will be needed with respect to the magnitude and timing of any easing, so that it occurs only after inflation pressures have abated and it is clear that the fiscal resources exist to reduce taxes or increase spending. Several Directors encouraged the authorities to save any revenue overperformance in 2008/09 (July-June), as they had in previous years.

Directors considered that the current tightened stance of monetary policy is appropriate. During 2007, retail mortgage rates became more responsive to increases in the official cash rate, moderating house price inflation and slowing overall activity. More recently, tightening international credit conditions have contributed to further mortgage rate increases, reducing credit demand. Directors concurred that monetary policy should remain on hold pending clearer indications of the risks and the future path of the economy.

Directors observed that inflows of foreign capital, attracted by wide interest rate differentials, and strong commodity prices_-particularly for New Zealand's dairy products—have contributed to an appreciation of the currency. Directors noted that as inflation pressures moderate and the policy interest rate normalizes, capital inflows should ease and the exchange rate 
depreciate. However, the equilibrium level of the real effective exchange rate is likely to remain above its historical average, because a portion of the rise in commodity prices will likely be permanent.

Directors noted that the financial sector remains sound. Banks are profitable, well capitalized, and the quality of their assets appears to be high. Banking sector vulnerabilities present some policy challenges, however. Banks' assets are concentrated in residential mortgages, and banks have significant exposure to the short-term international wholesale funding markets. The current tightening in international capital markets is putting upward pressure on bank funding costs and highlighting rollover risks. Directors acknowledged that disruption to foreign capital inflows that raises demand for domestic liquidity would need to be accommodated by the RBNZ. They agreed with the measures to improve access to liquidity from the RBNZ. They also welcomed the steps taken by the RBNZ to review its liquidity policy for banks to encourage the diversification of funding sources and the lengthening of maturities.

Public Information Notices (PINs) form part of the IMF's efforts to promote transparency of the IMF's views and analysis of economic developments and policies. With the consent of the country (or countries) concerned, PINs are issued after Executive Board discussions of Article IV consultations with member countries, of its surveillance of developments at the regional level, of post-program monitoring, and of ex post assessments of member countries with longer-term program engagements. PINs are also issued after Executive Board discussions of general policy matters, unless otherwise decided by the Executive Board in a particular case. The staff report (use the free Adobe Acrobat Reader to view this pdf file) for the 2008 Article IV Consultation with New Zealand is also available. 
New Zealand: Selected Economic Indicators

\begin{tabular}{|c|c|c|c|c|c|c|}
\hline & 2004 & 2005 & 2006 & 2007 & $\begin{array}{l}\text { Proj. } \\
2008\end{array}$ & $\begin{array}{l}\text { Proj. } \\
2009\end{array}$ \\
\hline \multicolumn{7}{|l|}{ Real economy (percent change) } \\
\hline GDP (production basis) & 4.4 & 2.7 & 1.5 & 3.1 & 2.0 & 2.1 \\
\hline Final domestic demand & 7.2 & 4.6 & 1.9 & 4.5 & 2.7 & 2.0 \\
\hline Exports of goods and services & 5.9 & -0.4 & 1.8 & 3.5 & 5.4 & 4.0 \\
\hline Imports of goods and services & 16.0 & 5.4 & -2.7 & 8.8 & 5.9 & 3.5 \\
\hline Headline CPI inflation (end of period) & 2.7 & 3.2 & 2.7 & 3.2 & 3.1 & 2.5 \\
\hline Unemployment rate (in percent) & 3.9 & 3.7 & 3.8 & 3.6 & 3.9 & 4.3 \\
\hline National saving (in percent of GDP) $1 /$ & 18.2 & 16.0 & 14.5 & 15.7 & 14.8 & 14.4 \\
\hline Investment (in percent of GDP) & 24.6 & 24.5 & 23.1 & 23.6 & 21.9 & 21.7 \\
\hline \multicolumn{7}{|l|}{ Government budget (in percent of GDP) 2/ } \\
\hline Revenue & 32.9 & 34.4 & 37.5 & 34.6 & 35.0 & 34.0 \\
\hline Expenditure & 29.1 & 30.5 & 31.6 & 32.1 & 32.1 & 32.4 \\
\hline Operating balance before gains and losses & 3.9 & 4.7 & 4.5 & 3.2 & 3.7 & 2.3 \\
\hline Net Crown debt including NZS Fund & 7.3 & 2.8 & -1.3 & -5.1 & -7.9 & -9.5 \\
\hline \multicolumn{7}{|l|}{ Money and credit (end of period) } \\
\hline$M 3$, resident (change in percent) & 3.5 & 9.4 & 11.3 & 11.1 & $\ldots$ & $\ldots$ \\
\hline Private domestic credit (change in percent) & 12.2 & 10.2 & 12.4 & 12.8 & $\ldots$ & $\ldots$ \\
\hline Interest rate (90-day, in percent) $3 /$ & 6.8 & 7.7 & 7.7 & 8.9 & 8.9 & $\ldots$ \\
\hline Government bond yield (10-year, in percent) $3 /$ & 6.0 & 5.7 & 5.9 & 6.4 & 6.6 & $\ldots$ \\
\hline \multicolumn{7}{|l|}{ Balance of payments (in percent of GDP) } \\
\hline Current account balance & -6.4 & -8.5 & -8.6 & -7.9 & -7.1 & -7.3 \\
\hline Trade balance (goods) & -1.4 & -2.4 & -1.9 & -1.3 & 0.7 & 0.9 \\
\hline Terms of trade (change in percent) & 6.3 & 1.1 & 0.0 & 6.0 & 6.5 & 0.6 \\
\hline \multicolumn{7}{|l|}{ External assets and liabilities (in percent of GDP) } \\
\hline Official reserves (NZ\$ billion) $4 /$ & 9.7 & 13.1 & 19.9 & 22.3 & 24.5 & $\ldots$ \\
\hline Gross external debt & 107.3 & 106.3 & 115.1 & 119.9 & 122.0 & 124.6 \\
\hline Net international investment position & -84.0 & -84.8 & -87.9 & -87.2 & -90.0 & -93.4 \\
\hline \multicolumn{7}{|l|}{ Exchange rate (period average) } \\
\hline US\$/\$NZ 3/ & 0.66 & 0.70 & 0.65 & 0.74 & 0.79 & $\ldots$ \\
\hline Trade-weighted index (June $1979=100) 3 /$ & 66.5 & 70.4 & 65.4 & 70.9 & 71.2 & $\ldots$ \\
\hline Nominal effective exchange rate $5 /$ & 128.1 & 134.3 & 123.8 & 133.0 & 135.0 & $\ldots$ \\
\hline Real effective exchange rate 5/ & 130.1 & 137.6 & 128.1 & 137.7 & 139.6 & $\ldots$ \\
\hline
\end{tabular}

Sources: Data provided by the New Zealand authorities; and Fund staff estimates and projections.

$1 /$ Based on national accounts data.

2/ Fiscal years ending June 30.

3/ Data for 2008 are as of end-April.

4/ Data for 2008 are as of end-March.

5/ IMF Information Notice System index $(1990=100)$. Data for 2008 are as of end-February. 